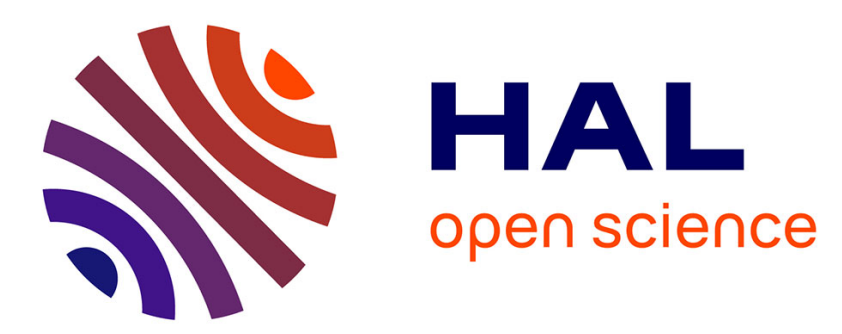

\title{
Skilled labor supply, IT-based technical change and job instability
}

Luc Behaghel, Julie Moschion

\section{To cite this version:}

Luc Behaghel, Julie Moschion. Skilled labor supply, IT-based technical change and job instability. 2011. halshs-00646595

\section{HAL Id: halshs-00646595 \\ https://shs.hal.science/halshs-00646595}

Preprint submitted on 30 Nov 2011

HAL is a multi-disciplinary open access archive for the deposit and dissemination of scientific research documents, whether they are published or not. The documents may come from teaching and research institutions in France or abroad, or from public or private research centers.
L'archive ouverte pluridisciplinaire HAL, est destinée au dépôt et à la diffusion de documents scientifiques de niveau recherche, publiés ou non, émanant des établissements d'enseignement et de recherche français ou étrangers, des laboratoires publics ou privés. 


\section{PARISSCHOQL OF ECONOMICS}

WORKING PAPER N² 2011 - 39

Skilled labor supply, IT-based technical change and job instability

Luc Behaghel

Julie Moschion

JEL Codes: J23; J24; J41

Keywords: Technical change; labor turnover; Skill bias; Job security; Internal labor markets

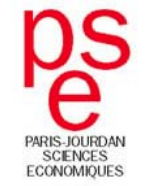


November 2011

\title{
Skilled labor supply, IT-based technical change and job instability*
}

\author{
Luc Behaghel \\ Paris School of Economics-INRA ${ }^{1}$ and CREST \\ PSE, 48 Boulevard Jourdan, 75014 Paris, France \\ Email: luc.behaghel@ens.fr
}

Julie Moschion

Melbourne Institute of Applied Economic and Social Research

Email : moschion@unimelb.edu.au

\footnotetext{
* We are grateful to Eve Caroli and John Van Reenen for their insights. Maria-Eugenia Baez provided excellent research assistance. Data was made available through the Réseau Quételet; we are particularly grateful to Alexandre Kych at Centre Maurice Halbwachs for his help with the data. This work was supported by the French Agence Nationale de la Recherche [grant number ANR-08-JCJC-0067-01].

${ }^{1}$ UMR 8545(PSE), F-75014, Paris France
} 


\begin{abstract}
In this paper, we provide empirical evidence on the impact of IT diffusion on the stability of employment relationships. We document the evolution of the different components of job instability over a panel of 350 local labor markets in France, from the mid 1970s to the early 2000s. Although workers in more educated local labor markets adopt IT faster, they do not experience any increase in job instability. More specifically, we find no evidence that the faster diffusion of IT is associated with any change in job-to-job transitions, and we find that it is associated with relatively less frequent transitions through unemployment. Overall, the evidence goes against the view that the diffusion of IT has spurred job instability. Combining the local labor market variations with firm data, we argue that these findings can be explained by French firms' strong reliance on training and internal promotion strategies in order to meet the new skills requirement associated with IT diffusion.
\end{abstract}

Keywords: Technical change; labor turnover; skill bias; job security; internal labor markets.

JEL codes: J23; J24; J41. 


\section{Introduction}

Among the questions raised by IT-based technical change among labor economists, one remains unsettled: to what extent has the diffusion of IT over the past decades modified the stability and the security of employment relationships?

Several theoretical arguments predict that a rapid diffusion of IT should result in higher job instability. In Schumpeterian models, IT-based technical change, just like any form of technical change, goes through a creative destruction process. The reallocation of workers across sectors or firms is part of that process. In a frictionless labor market, this may simply result in more frequent job-to-job transitions; in the presence of matching frictions, it may also create job insecurity, characterized by transitions from employment to unemployment. ${ }^{2}$ This first argument is not specific to IT. A second argument is related to the role of IT in the "new economy", where firms create more value by the rapid introduction of new products and services rather than by the continuous improvement of production processes. The perpetual re-composition of the firms' workforce is part of this post-Fordist model, as a way to introduce new talent and to develop creative approaches (Reich, 2001). IT diffusion may facilitate it by allowing firms to codify their processes, making it easier for new workers to adapt quickly, and limiting the knowledge loss associated with the exit of more experienced workers (Caroli, 2007). Yet, balancing these two arguments, there are also theoretical reasons to believe that stable employment relationships are compatible with IT diffusion. The external labor market is only one source at which firms may find the skills they need; internal labor markets are another one. As argued by Mincer (1989), the long-run response to technical change and the need of new skills may well be on-the-job training rather than costly worker flows.

In this paper, we provide empirical evidence on the impact of IT diffusion on the stability of employment relationships. We document the evolution of the different components of job instability over a panel of 350 local labor markets in France, from the mid 1970s to the early 2000s. Although workers in more educated local labor markets adopt IT faster, they do not experience any increase in job instability. More specifically, we find no evidence that the faster diffusion of IT is associated with any change in job-to-job transitions, and we find that it is associated with relatively less frequent transitions to unemployment. Overall, the

\footnotetext{
${ }^{2}$ Following the literature, we define job instability as the sum of voluntary and involuntary job exits, and define job insecurity as involuntary worker flows only, which we characterize through transitions from employment to unemployment (Mottschalk and Moffit, 1999).
} 
evidence goes against the view that the diffusion of IT has spurred job instability. In a second part of the paper, we combine the local labor market variations with firm data. We argue that the persistence of stable employment relationships can be explained by French firms' strong reliance on training and internal promotion strategies in order to meet the new skills requirement associated with IT diffusion.

The first contribution of our analysis is to rely on differences in IT adoption across labor markets, an unusual source of variation to study the impact of IT on employment relationships. ${ }^{3}$ Other papers have used comparisons across industries (Neumark and Reed, 2004; Givord and Maurin, 2004) or across firms (Bauer and Bender, 2004; Behaghel, Caroli and Walkowiak, 2011), yielding quite contrasted results. We discuss the methodological and substantial differences that may explain these differences.

Our second contribution is to connect this empirical investigation of the impact of IT to the theoretical and empirical literature on the causes of IT adoption. Pursuing a tradition in the economic history literature (Habakkuk, 1962; Goldin and Sokoloff, 1984), Caselli (1999) and Acemoglu (2007) have stressed the endogeneity of IT adoption and more particularly the role of initial factor endowments. Such models have been extended and applied to local labor markets by Beaudry, Doms and Lewis (2010), who show that the adoption of PCs across U.S. cities is significantly driven by the initial skill mix. We find similar results for France: a worker located in a local labor market with initially high supply of skills tends to adopt IT faster, even after controlling for his own education and for the firm's characteristics. We argue that these local patterns in PC adoption are plausibly exogenous to the evolution of employment stability and use them to tentatively estimate a causal, aggregate impact of IT diffusion on employment stability.

Last, analyzing firm human resource strategies is a first step in uncovering the mechanisms through which technical change modifies the employment relationship. Our results support Mincer's insight that the effects of technical change are mediated by firms' adaptation strategies.

The first section of the paper details our empirical approach and relates it to the literature. The second section presents the data and displays some graphical evidence. The next three sections detail the results: the impact of the initial local skill mix on IT adoption, job

\footnotetext{
${ }^{3}$ An exception is Neumark and Reed (2004) who (among other things) investigate the prevalence of contingent and alternative employment relationships in high-tech cities.
} 
instability, and firm human resource strategies. The last section offers some concluding comments and underlines remaining questions.

\section{Related literature and empirical strategy}

Over the past few years, the micro-econometric literature on technical and organizational changes has made considerable progress in understanding patterns of IT adoption. Even though the main driving source of IT-based technical change - the dramatic fall in the real cost of computers - is an economy-wide force, IT adoption patterns significantly differ across firms, industries, and places ${ }^{4}$. At the firm level, recent papers have shown that the type of ownership matters, with family-owned businesses less likely to adopt new organizational methods, the opposite being true for multinationals (Bloom and Van Reenen, 2010). At the industry level, the share of routine tasks in 1960 is a strong predictor of subsequent IT adoption (Autor, Levy and Murnane, 2003); international trade and specifically import competition from China may also have induced technical change (Bloom, Draca and Van Reenen, 2009). Lastly, at the city (or local labor market) level, the local supply of skilled labor predicts substantial differences in computer usage rates (Doms and Lewis, 2006; Beaudry, Doms and Lewis, 2010).

All these findings are interesting per se: they reveal comparative advantages for IT, which may have large consequences on inequalities across individuals, sectors and areas. But they are also disturbing findings for the (older) empirical literature that attempts to measure the consequences of IT adoption. Take the consequences of IT on wage inequalities, for instance. All the above factors - firms' ownership and management type, competitive pressure from imports, trade and immigration shocks - confirm that the adoption of IT is endogenous, motivating the search for instruments; but none of these factors can directly be considered as a plausible instrument. Indeed, the restriction exclusion does not hold: wage policies are likely to be directly impacted by firms' management types and ownership; import competition puts pressure on wages in a way that may directly impact wage inequalities; and the local supply of skilled labor has equilibrium effects on relative wages. The literature on IT adoption has therefore been particularly careful not to claim that these sources of variations provide valid instruments to explore the wage effects of IT. This has led to a somewhat disturbing split between the strand of research that documents the endogeneity of IT adoption and a second

\footnotetext{
${ }^{4}$ At the worker level, the finding that unskilled workers have a lower propensity to use computers has been a major ingredient in the empirical literature on skill-biased technical change.
} 
strand of the literature exploring IT impacts under exogeneity assumptions that appear more and more fragile.

Our view is that the first strand of the literature, although it does not provide bullet-proof instruments, may be used to build plausible difference-in-difference strategies. Take the papers by Beaudry, Doms and Lewis on the impact of local differences in skilled labor supply. In an earlier version of their paper, the authors document the negative correlation between the relative wage and the relative supply of educated workers across cities in the U.S., as of 1970. This negative correlation is consistent with the expected equilibrium effect. That correlation diminishes over time until becoming almost 0 in 2000 (Beaudry, Doms and Lewis, 2006, figures $8 \mathrm{a}$ to $8 \mathrm{~d}$ ). The question is: can we attribute (part of) the change in the correlation to differential patterns of PC diffusion? Just like for any difference in differences, all that can be said is: to the extent that local labor markets with different skills endowments would have witnessed parallel trends in equilibrium relative wages in the absence of IT diffusion, the relative increase in the wage of more educated workers in areas with a more educated workforce can be attributed to computer adoption. Even though it is conditional, this statement is informative. In the absence of fully conclusive evidence, it is even quite useful.

The strategy we propose in this paper is similar: we use initial differences in skilled labor endowments across local labor markets to perform two difference-in-difference analyses. Did local labor markets with a more educated workforce adopt computers faster? Did the same local labor markets witness a larger increase in job instability? If yes, and to the extent that these local labor markets would have displayed similar trends without IT diffusion, differential evolutions in job instability can be attributed to the diffusion of PCs. Let $I T_{c}$ be a measure of IT use in local labor market $c, E d u c_{c 0}$ the initial supply of skilled labor, and $T_{c}$ a measure of job instability. Our strategy, in its simplest form, amounts to estimating two reduced-form equations, looking at differences in evolutions across local labor markets:

$$
\begin{aligned}
\Delta I T_{C} & =\beta \text { Educ }_{\mathrm{c} 0}+\varepsilon_{\mathrm{c}}, \\
\Delta T_{c} & =\alpha \text { Educ }_{\mathrm{c} 0}+\mathrm{v}_{\mathrm{c}} .
\end{aligned}
$$

If the "parallel trend" assumption holds, then $\gamma \equiv \alpha / \beta$ is the impact of IT diffusion on labor market transitions. This difference-in-difference approach can be rephrased as an IV approach. Write the equation of interest as

$$
\Delta T_{c}=\gamma \Delta I T_{C}+\mathrm{m}_{\mathrm{c}} .
$$


Then, the parallel trend assumption amounts to the exclusion restriction $\mathrm{E}\left(\mathrm{m}_{\mathrm{c}} \mathrm{Educ}_{\mathrm{c} 0}\right)=0$ and $\gamma$ can be consistently estimated by IV using Educ $_{\mathrm{c} 0}$ as an instrument.

Clearly, this empirical strategy is not above criticism. There may be reasons why the parallel trend hypothesis would not hold. It is however a clear improvement over a direct estimation of equation (3) by OLS. Indeed, any idiosyncratic shock that affects a given local labor market - say, a positive demand shock on the market for goods - is likely to impact the ability of firms to invest in IT and to retain their workforce. This creates a bias in the OLS estimate, but not on the IV as long as demand shocks are evenly distributed across initially more or less educated local labor markets.

How does this strategy relate to the emerging literature on the impact of IT-based technical change on job instability?

Firm-level variations have been used in particular by Bauer and Bender (2004) for Germany, and Behaghel, Caroli and Walkowiak (201) for France. A necessary identifying assumption is that firm heterogeneity (for instance, unobserved managerial capacity) that drives the adoption of IT has no direct impact on worker flows. Bauer and Bender (2004) use lagged values of the adoption of IT or innovative workplace practices to mitigate endogeneity concerns; however, as they acknowledge, this does not reduce the risk of spurious correlation due to permanent unobserved heterogeneity, or to the fact that technical and organizational changes may be introduced in reaction to anticipated shocks. The results obtained by the two papers are contrasted. Bauer and Bender (2004) find that new technologies increase churning rates for skilled and unskilled workers. By contrast, Behaghel et al. (2011) find that, although the introduction of new IT is associated with an upward shift of the occupational structure within firms, about two-third of it occurs through promotion rather than through the entry and exit of workers. Moreover, IT adoption is not associated with excess turnover. Behaghel et al. (2011) argue that this is consistent with the large diffusion of internal labor markets in France, whereas occupational labor markets are dominant in Germany (Marsden, 1999).

Variations across sectors are used Givord and Maurin (2004), for France. They study the evolution of involuntary job loss in France between 1982 and 2002, with the French Labor Force Survey. Their results indicate that job insecurity is higher in the 1990s than in the 1980s. This increase in job loss rates appears to be more important in sectors where workers use new technologies more intensively. ${ }^{5}$ They conclude that technological change contributes

\footnotetext{
${ }^{5}$ Givord and Maurin use a classification with 38 sectors.
} 
to increasing job insecurity. The underlying assumption is that without the adoption of new technologies, the evolution of job insecurity across sectors would have been identical. This assumption is violated if shocks at the sector level affect job security in some sector and not in others, or if macroeconomic shocks have a differentiated impact across sectors. Another limitation has to do with the direct comparison of sectors with high and low IT adoption patterns, without identifying the reasons of differential adoption. It is plausible that some sectors respond to shocks like import competition by adopting new technologies more aggressively (as argued by Bloom et al., 2010) and by changing their human resource management practices (for instance, switching from long-term employment relationship to short-term ones, as shown by Bertrand, 2004 ${ }^{6}$ ).

Last, working on U.S. cross-section but with different sources of variation, Neumark and Reed (2004) have contrasted results. They find a significantly greater use of contingent and "alternative" employment relationships in jobs located in cities classified as high-tech. They also use cross-industry variations, with contrasted results: they find a greater use of contingent and alternative employment relationships in fast-growing industries, but a lesser use of this type of contracts in high-tech industries.

Overall, the picture is mixed enough to warrant a different look at the evidence, under the reasonable assumptions of a difference-in-difference comparison across local labor markets with a more or less educated workforce.

\section{Data and graphical evidence}

Our test of the impact of local skill endowment requires data at the local labor market level over a sufficient time span. We created a database at the level of the zones d'emploi ("employment areas"). The 348 zones d'emploi constitute a partition of the French territory; they were delimited by the French statistical institute (INSEE) and the Ministry of Labor on the basis of data on commuting from the 1990 population census; we use this partition throughout the period. The working age population of a given zone d'emploi can be thought of as the potential labor supply faced by local firms; in what follows, we will use the term of "local labor market" for zone d'emploi.

\footnotetext{
${ }^{6}$ Bertrand (2004) analyzes the impact of import competition (instrumenting industry-level measures of import penetration with source-weighted industry exchange rate) on the wages of incumbent workers. However, other components of the employment relationship, like job stability, may well be impacted to.

${ }^{7}$ Those include independent contractors, on-call workers, temporary help agency workers, and workers provided by contract firms.
} 
Measures of the initial skill mix come from the 1975 population census. We had access to tabulations from the exhaustive data. As a measure of the initial skill endowment for a given local labor market, $E d u c_{c 0}$, we use the share of the working age population (aged 20 to 59) holding a high-school degree or more. Variations in Educ $c 0$ are substantial: the (unweighted) mean across local labor markets is $12.9 \%$, with a standard deviation of $4.5 \%$. The gap between the $9^{\text {th }}$ and the $1^{\text {st }}$ deciles is about $10 \mathrm{pp}(=18.6-8.7)$. As shown on figure 1 , more educated workers are concentrated in the South and the greater Paris area. Spatial correlations are strong (22 regional dummies explain $27 \%$ of the variance over the 348 local labor markets). Moreover, differences in skill mix are correlated with differences in population density (figure 2). However, the correlation is far from perfect: for instance, the North is densely populated, but its population has relatively low educational attainment. Another feature of the data is the remarkable stability of endowment differences over time, as shown by comparing the maps in 1975 and 1999 (figure 3). The correlation coefficient between skill endowments at these two dates is equal to .9. Overall, there is a strong and stable dispersion in skill endowment over the French territory. Only part of it can be explained by the presence of cities and variation in population density. A likely hypothesis is that, similarly to what happened in the US (Moretti, 2004), a significant determinant of these local differences has to do with the history of the expansion of education in France in the late $19^{\text {th }}-$ early $20^{\text {th }}$ centuries.

Consistent series on technology at use at the local level are rare in France. Firm surveys asking for information on software and hardware investments only start in the late 1990s and often have data at the firm rather than at the plant level, making it hard to analyze geographical repartitions. We therefore rely on supplements to the French Labor force survey (Enquête Emploi, thereafter called the LFS) in 1987, 1991, 1993, 1998 and 2005. These supplements ask workers detailed questions on their working conditions and the tools they use at work. Given our focus on IT, we construct two main indicators, one for the use of a personal computer at work (data available from 1987 to 2005), the other for the use of the Internet (available for 1998 and 2005). Figure 4 displays the adoption patterns for PCs and the Internet, separately for high-school graduates and high-school dropouts.

Lastly, we rely on the 1975 to 2002 issues of the French LFS to compute year-to-year transition rates on the labor market. Over that period, the French LFS takes place each year in 
March as a 3-year rotating panel with a 1/300 sampling rate $^{8}$. Following the literature, we compute indicators for job instability and job insecurity based on transition rates out of a given job. Specifically, we consider two indicators for job insecurity: transitions from employment to unemployment and transitions from employment to non employment. The two are computed based on transitions between year $y$ and $y+1$ among all wage earners aged 20 to 58. The second indicator includes transition to unemployment and transitions out of the labor force ${ }^{9}$; the key reason for including transition out of the labor force is the prevalence of early retirement schemes for workers above 55 . Workers in early retirement will mostly declare themselves as out of the labor force (although some of them are technically receiving unemployment benefits). More fundamentally, early retirement schemes have been widely used as a less painful way for firms to adjust their workforce, often leaving workers with no better choices; it is therefore probably warranted to include these forced transitions in the job insecurity indicator. Nonetheless, this may overstate job insecurity as it also includes, for instance, women who stop working to raise their children. We therefore follow the two indicators. As a third component of job instability, we consider yearly job-to-job transitions. A complete measure of worker flows (at a yearly frequency) could be obtained by adding the job-to-job and the employment to non employment transition rates.

In contrast to the persistent debate in the US (see Stevens, 2005, and Farber, 2007 and 2010), there is little doubt on the existence of a long-term trend in rising job insecurity in France (see Givord and Maurin, 2004). Figure 5 displays the overall trend. Transitions from employment to unemployment and from employment to non employment appear to rise significantly over the period, despite pauses in years of economic expansions (late 1980s, late 1990s). On average, transition rates appear to increase by more than $2 \mathrm{pp}$ for high-school dropouts and by about $1.5 \mathrm{pp}$ for high-school graduates. This roughly corresponds to a multiplication by a factor of 2. In contrast, job-to-job transitions display no clear trend, and they are strongly procyclical. Overall, the strong increase in job insecurity motivates digging further into the potential explanatory role of IT adoption over the period.

We now turn to graphical evidence on the link between skilled labor endowment and the adoption of IT. To do so, we split the 348 local labor markets into 4 quartiles in terms of

\footnotetext{
${ }^{8}$ From 1968 to 2002, the households included in the Labor Force Survey sample were interviewed in March of three consecutive years with one-third of the households replaced each year. Since 2003, the households included in the French LFS are interviewed six consecutive quarters with one-sixth of the households replaced each quarter. To avoid the break in series, we stop the analysis in 2002. This covers the main period of diffusion of the PC.

${ }^{9}$ Transitions toward retirement are not included: the minimal retirement age is 65 until 1982 and 60 afterwards.
} 


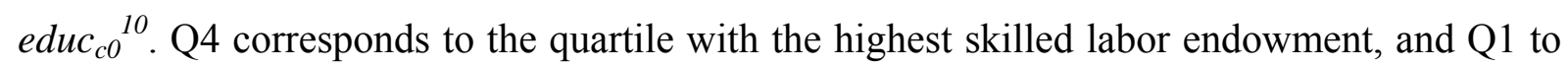
the quartile with the lowest endowment. We then compute usage rate within each quartile, in various years. ${ }^{112}$ As shown by figure 6, there is a clear correlation between $E d u c_{c 0}$, the initial endowment of skilled labor, and the adoption of computers 20 years later. This correlation holds even after controlling for the worker's education by looking separately at high-school dropouts and high-school graduates. Interestingly, differences in usage rates are higher for high-school dropouts than for high-school graduates, in absolute as well as in relative terms. In 1993, for instance, the probability that a high-school dropout located in a local labor market with a low endowment in educated labor (1st quartile) uses a PC at work is only $10 \%$. It is almost $15 \mathrm{pp}$ higher for a high-school dropout located in well-endowed local labor market $\left(4^{\text {th }}\right.$ quartile). The same difference is closer to $10 \mathrm{pp}$ for high-school graduates, on a basis of $40 \%$. This first pass on the data seems to confirm the hypothesis that the local supply in educated labor may be a driver of IT adoption (even after controlling for the individual worker's education). A last element to notice is the fact that the gap in adoption seems to narrow between 1993 and 1998. This suggests that the difference in local adoption patterns may be transitory and fade out once IT has spread to all firms.

Are these systematic differences in the diffusion of IT paralleled by systematic differences in the evolution of job insecurity and job instability? Figures 7,8 and 9 do not suggest any systematic pattern. Figure 7 displays transition rates from employment to unemployment. In each figure, the top two graphs display means by quartiles of $E d u c_{c 0}$ and by year; to reduce the noise due to sampling error or temporary shocks, the bottom two graphs display the same data but grouping the top two and the bottom two quartiles, and grouping years two by two. The four quartiles of local labor markets display very similar trends - a strong increase over the period, with decreases in periods of economic expansion (late 1980's and 1990's). There is no evidence of divergence in the trajectories. The same holds for transitions from employment to non employment. The picture for job-to-job transitions is somewhat more complex. Initially, transitions in local labor markets with a more educated workforce are substantially more frequent. For high-school dropouts, the differences seem to decline in the late 1970s. For high-school graduates, the two curves remain roughly parallel.

\footnotetext{
${ }^{10}$ Local labor markets are weighted by the size of their working age population, as of 1975.

${ }^{11}$ The French LFS is a clustered sample, so that some local labor markets are present in some years, and not in the others. Regression analysis with local labor market dummies in the next section will control for possible composition effects due to local labor markets entering and exiting the sample.

${ }^{12}$ Unfortunately, due to the break in the LFS between 2002 and 2003, we were not able to retrieve data by local labor markets in 2005 . We therefore only have one data point - 1998 - for the use of the Internet.
} 
Overall, if anything this preliminary graphical analysis confirms the hypothesis that the adoption of IT is well predicted by the initial supply of skilled labor; however, there is no evidence of an increase in job insecurity in local labor markets endowed with a more educated workforce. Patterns for job-to-job transitions are less clear-cut, if anything, they suggest that the adoption of new technologies in local labor markets with a less educated workforce has been associated with less job-to-job transitions. The next two sections use regression analysis to confirm these preliminary findings.

\section{Initial skill mix and the use of IT}

In this section, we study the correlation between the local level of human capital in 1975 and the adoption of IT. Previous studies demonstrated a positive association between the initial skill mix and the use of computers in the United States (Beaudry, Doms and Lewis, 2010). We assess this correlation for France and extend the analysis to the use of the Internet.

Specifically, we estimate the partial correlation between the share of high-school graduates in 1975 in a given local labor market $\left(\right.$ Educ $\left._{\mathrm{c} 0}\right)$ and the individual use of computers and the Internet in 1998:

$$
\mathrm{I}_{\mathrm{ic}}=\alpha \mathrm{Educ}_{\mathrm{c} 0}+\lambda \mathrm{X}_{\mathrm{ic}}+\varepsilon_{\mathrm{ic}}
$$

where $\mathrm{I}_{\mathrm{ic}}$ are dummy variables indicating whether an individual $i$ in local labor market $c$ used a computer (or the Internet) at work in 1998. A positive $\alpha$ indicates that the use of computers (or the Internet) is higher in local labor markets which were more educated in 1975 . We consider different sets of control variables $X_{i c}$. Individual controls account for the fact that individual characteristics could partly explain differences in the probability to use computers and the Internet. We use the following set of individual characteristics: sex, age (5-year dummies), tenure (year dummies for tenure between 1 and 4 years and 5 -year dummies for tenure over 4 years), diploma (6 dummies), occupation (6 dummies), industry (16 dummies), plant size (5 dummies), and place of residence ( 9 categories: urban/rural, and city size brackets). In addition to these individual controls, some specifications include controls for 
possible confounding factors at the local labor market level: population density in 1975 (simple and squared), share of the labor force aged 40 and more in 1975.

Table 1 gives the main results, confirming the graphical evidence of the previous section. Column 1 of Panel A shows that a 10 percentage point increase in the share of high-school graduates in $1975^{13}$ is associated with a $14.7 \mathrm{pp}$ increase in the use of computers in 1998 . The correlation is strikingly high; it is also very precisely estimated due to the large sample size. It may encompass three effects. First, workers located in 1998 in a local labor market that had a more educated workforce in 1975 also tend to be more educated workers on average in 1998 (see the persistence between figures 1 and 3). If computers and education are complement at the workplace level, this may induce higher adoption of computers, through a composition effect. Second, if technological choices at the firm level are driven by the local supply of skilled labor, there will be a positive partial correlation between being located in a local labor market with a more educated workforce and using computers, irrespective of one's own education level. Third, a positive $\alpha$ may capture any other spurious correlation due to unobserved local labor market factors. Concerning the first point, controlling for individual characteristics does reduce the correlation. However, the estimate is still sizeable: a $10 \mathrm{pp}$ increase in the initial skill mix is associated with a $12.4 \mathrm{pp}$ increase in the probability of using a computer, after controlling for one's own education level and for a variety of other workplace characteristics (column 2): a large part of the correlation indeed seems to be due to the worker's environment. Finally, adding controls for other local labor market characteristics such as population density and the age pyramid only marginally reduces the correlation (column 3). Overall, these results confirm the graphical analysis performed in the previous section: initial skill endowments are a strong predictor of IT adoption, and this holds true even after accounting for composition effects and for simple confounding factors at the local labor market level.

Panel B also shows a positive association between the share of high-school graduates in 1975 and the use of the Internet for work, even though the point estimate is lower (implying increases between 6.3 and $8.1 \mathrm{pp}$ for a $10 \mathrm{pp}$ increase in the initial skill mix).

\footnotetext{
${ }^{13}$ Equivalent to going from the $1^{\text {st }}$ to the $9^{\text {th }}$ decile in the distribution of initial skill mix across local labor markets.
} 
These effects may be heterogeneous across subgroups as different populations could benefit differently from being in a more or less educated environment (Table 2). Whatever the individual level of education, gender and age, everyone adopts IT more if based in an initially educated area. The use of computers (resp. the Internet) increases by at least 10.9 pp (resp. 6.7 pp) when the share of high-school graduates in 1975 increases by $10 \mathrm{pp}$. Results also suggest that the use of computers is even more strongly associated with the initial skill mix for older workers and high-school dropouts, whose use of computers is traditionally lower than other categories. The use of the Internet is particularly stimulated by the initial skill mix for older workers and high-school graduates, as the use of the Internet was usually associated with managerial responsibilities. These differences notwithstanding, the homogeneity in the impact of the initial skill mix is striking given the heterogeneity in mean usage rates across groups. Everything seems to work as if being in a local labor market with a more educated workforce was shifting the whole pattern of IT use for all groups of workers. This is consistent with the view that skilled and unskilled workers are simultaneously impacted by technological choices made at the firm level.

\section{Initial skill mix and job instability}

In this section, we assess whether local differences in human capital endowment in 1975 predict diverging transition patterns (worker flows) on local labor markets. To the extent that local differences in human capital endowment in 1975 should have no direct impact on the evolution of local worker flows, and that any effect should come from IT adoption, this can be viewed as a reduced form test of the prediction that IT-based technical change affects the different components of job instability.

As discussed in section 1, our strategy is reminiscent of a difference-in-difference approach where differences are taken across periods and local labor markets, but where the treatment variable (the initial skill mix) is continuous. We estimate the following equation:

$$
\mathrm{S}_{\mathrm{ict}}=\theta \operatorname{Educ}_{\mathrm{c} 0} * \mathrm{t}+\sum \zeta_{\mathrm{c}} 1_{\mathrm{c}}+\sum \gamma_{\mathrm{t}} 1_{\mathrm{t}}+\beta \mathrm{X}_{\mathrm{ict}}+\eta_{\mathrm{ict}}
$$

where $S_{\text {ict }}$ are dummy variables indicating whether an individual experienced a transition from employment to another status (non employment, unemployment or another job) between year $y$ and year $y+1$. $t$ is a linear time trend (in years). $\theta$ is the parameter of interest: it corresponds to the yearly increase in transition rates associated with a higher initial skill mix. A positive 
estimated value of $\theta$ indicates that a higher share of high-school graduates in 1975 is associated with more transitions between 1975 and 2002. $1_{\mathrm{c}}$ are dummies for the 348 local labor markets and $1_{t}$ are year dummies. Permanent unobserved sources of differences in transition rates at the local labor market level are therefore controlled for.

Regressions also include individual controls $X_{\text {ict }}$ : sex, age, tenure, diploma, socio-professional category, sector, size of the establishment, size of the city. These controls account for the fact that individual characteristics partly determine individual transition outcomes. Individual controls are also interacted with a trend to control for the fact that the effect of individual characteristics may evolve.

In more complete specifications, we also introduce the share of high-school graduates in 1975 interacted with GDP and local labor market characteristics interacted with a trend: active population density in 1975 (simple and squared), share of the labor force aged 40 and more in 1975. The idea is that differences in initial local conditions could explain different evolutions of transition outcomes.

In contrast with the simple statement of the difference-in-difference strategy in equation (2), we choose to estimate equation (5) in levels and at the individual worker level to make the most of the sources of variation in the data. Just like in equation (4), the advantage of running the estimation at the individual level is to disentangle direct effects from contextual effects (being highly educated vs. being located in a local labor market with highly educated workers). One could alternatively use a two-step procedure to estimate local labor market times year fixed effect, net of the individual workers' characteristics. We checked that this two-step procedure makes little difference in practice. The important choice is to estimate the equation on levels rather than on first differences or long differences over time. Indeed, the panel is very unbalanced, due to the frequent entries and exits of local labor markets from the sampling frame of the LFS. This makes differencing quite unattractive. $\theta$ has the same interpretation as the coefficient from a first-differenced equation (that would be obtained by regressing yearly changes in transition rates on $E d u c_{c 0}$ ), without the drawback of dropping observations in any year.

Table 3 gives the results for the different transition outcomes and specifications. Panel A shows that a $10 \mathrm{pp}$ increase in the share of high-school graduates in 1975 reduces transitions to non employment between 1975 and 2002 by between 0.002 and 0.044 pp per year. The first specification, without any control, is consistent with figure 8: there is no raw correlation between the initial skill mix and the evolution of transition rates. However, a negative 
correlation appears when controlling for the impact of firm and worker characteristics. Globally, adding more controls does not alter the results: the effects are robustly negative. The magnitude of the effect is relatively large. Remember that the interdecile range for $E d u c_{c 0}$ is 10 pp. Over 27 years, the $95 \%$ confidence interval in the $4^{\text {th }}$ specification means that, everything else equal, workers in local labor markets at the $9^{\text {th }}$ decile of the initial skill mix experienced a relative decrease in job insecurity by between 0.66 and $1.72 \mathrm{pp}$ as compared to workers located in local labor markets at the $1^{\text {st }}$ decile. In other terms, working in a local labor market with an initially more educated workforce decreases the probability to become unemployed or inactive over the period.

Results are very similar for transitions to unemployment. Panel B shows that a $10 \mathrm{pp}$ increase in the share of high-school graduates in 1975 reduces transitions to unemployment by between 0.015 and $0.028 \mathrm{pp}$ per year. In all specifications, the estimated coefficient is significantly negative. Again, working in an initially more educated local labor market predicts a declining trend in job insecurity, when defining job insecurity as transitions from employment to unemployment. On the whole period, this corresponds to a fall in job insecurity of between 0.28 and $1.23 \mathrm{pp}$ ( $4^{\text {th }}$ specification $)$.

Concerning job-to-job transitions, we find no evidence of such a correlation. Panel C shows that a $10 \mathrm{pp}$ increase in the share of high-school graduates in 1975 has no effect on job-to-job transitions between 1975 and 2002 in most specifications. The confidence interval for the last specification is $[-0.31 ; 0.75]$.

Overall, effects do not go in the direction of IT-induced job instability: a more educated labor force in 1975 reduces the insecurity on the labor market and does not affect job-to-job transitions. As a result, the adoption of technological innovations, which is positively correlated with the initial skill mix, does not seem to increase transitions on the labor market.

We turn to disaggregated analysis by subpopulations. A first potential source of heterogeneity in our data is the individual level of education. Being in a local labor market which had more or less high-school graduates in 1975 could induce different evolutions of transition probabilities for high-school graduates and high-school dropouts. We also consider potential heterogeneity across gender and age. 
The disaggregated analysis provided in Table 4 uses the third specification of Table 3 which includes individual controls and the share of high-school graduates in 1975 interacted with GDP. Results suggest that in terms of transitions to non employment, both high-school graduates and high-school dropouts benefit from an initially educated background. Results also suggest that both men and women's transition to non employment are reduced in local labor markets where the share of high-school graduates in 1975 was higher. In contrast, only workers under 30 display lower transitions to non employment when living in initially more educated areas. This result is consistent with the finding from previous studies that technical and organizational changes benefit to younger workers compared to older workers (Aubert, Caroli, Roger, 2006).

Considering transitions to unemployment, the same type of heterogeneity appears: young workers are the ones who benefit the most from being in a local labor market which had more high-school graduates in 1975. Their transition probability to unemployment is lower by 0.054 pp per year between 1975 and 2002 in local labor markets with a share of high-school graduates in 1975 higher by 10 pp. High-school dropouts also show a significant negative effect of initial skill mix on the evolution of the transition probability to unemployment.

Job-to-job transitions do not vary with the local skill mix in 1975 and this is the case for all subgroups.

\section{Evidence on mechanisms: the role of training and promotions}

Interpreted causally, the above results imply that the adoption of IT reduces turnover ${ }^{14}$ in firms: indeed, job-to-job transitions are stable but transitions to non employment decrease. This may seem at odd with the literature on skill-biased technical change: if the adoption of IT is associated with a renewal of the workforce in order to meet the associated skills requirement, we would rather expect higher job instability, i.e. higher turnover. As noted in

\footnotetext{
${ }^{14}$ In what follows, we characterize the firm's turnover by the workers' exit rate, i.e. the ratio of workers exiting the firm in a given period over the initial size of the workforce. This is equivalent, from the worker's perspective, to job instability, characterized by the probability of exiting the firm (either to another job, or to non employment). Given the focus on job instability, we do not detail results on hirings here. Adding hiring rates to the analysis does not modify the overall picture (see Behaghel et al., 2011).
} 
the introduction though, firms need not rely on the external labor market (and increased churning rates): the alternative is to rely on internal labor market responses, typically by training and promoting incumbent workers. This, in turn, can result in lower job instability, if the joint human capital and IT investments make the employment relationship more profitable. This second interpretation is in line with the empirical evidence in Behaghel et al. (2011). In this section, we push the connection with that paper further, by linking the local labor and worker level data used in the previous sections with the same firm-level data they use. The purpose is to analyze to what extent the reduced form evidence found so far, and the arguably surprising results obtained, can be explained by the firms' human resources strategies.

We start by replicating the reduced form analysis of the two previous sections on firm data. ${ }^{15}$ IT adoption level is measured in firm $j$ located in local labor market $c$ through a firm survey conducted in 1998. The survey provides information on the proportion of workers using the Intranet ${ }^{16}$ and the Internet in 1998 (no use, less than $5 \%, 5$ to $19 \%, 20$ to $49 \%, 50 \%$ and more). We define a dummy variable $I T_{j c 98}$ equal to 1 if at least $5 \%$ of the workers use the Internet or at least $20 \%$ of the workers use the Intranet. With this definition, $33 \%$ of plants in the sample are "adopters" (meaning that $I T_{j c 98}$ is equal to 1 ). We estimate the following adoption equation:

$$
\mathrm{IT}_{\mathrm{jc} 98}=\mathrm{aEduc}_{\mathrm{c} 0}+\mathrm{m} \mathrm{X}_{\mathrm{jc} 98}+\varepsilon_{\mathrm{jc} 98}
$$

where $E_{\text {duc }}$ is the local labor market skill mix in 1975 (defined and measured as above), and $\mathrm{X}_{\mathrm{jc} 98}$ are control variables at the firm or at the local labor market level. ${ }^{17}$ This is the firm-level equivalent to the worker-level equation (4). A positive $a$ indicates that a more educated workforce in the local labor market predicts that firms located in that market are more likely to adopt advanced IT 25 years later. Results are in table 5. They are fully consistent with the predictions of endogenous technology adoption and with the worker-level evidence of table 1. Estimates of $a$ are statistically significant and economically large: the probability of using

\footnotetext{
${ }^{15}$ See Behaghel et al. (2011) and the data appendix for a presentation of the data, as well as for alternative specifications of the variables.

${ }^{16}$ The exact phrasing is 'Intranet and computer networks'.

${ }^{17} \mathrm{We}$ control for plant size (dummy variable for plants with more than 200 employees), being located on a labour market whose density is higher than the median, multi-establishment firms, public sector companies, listed companies, presence of union delegates, share of women in the labour force, part-time work (dummy variable for firms with more than 5\% of workers being part-time) and 15 sectors. The estimation uses robust standard errors, clustered at the local labor market level. About 250 local labor markets are represented in the sample.
} 
advanced IT is between 10 to 20 percentage points higher in firms located in local labor markets that were in the top half of the skill distribution 25 years earlier (compared to the bottom half of the distribution). This is a very large effect given that the average adoption rate in the sample is around $1 / 3$.

Similarly, we estimate the following reduced-form equation to explain exit rates from firms in different occupation groups:

$$
\mathrm{s}_{\mathrm{pjc} 9698}=\mathrm{b}_{\mathrm{p}} \operatorname{Educ}_{\mathrm{c} 0}+\mathrm{m}_{\mathrm{p}} \mathrm{X}_{\mathrm{jc} 98}+\varepsilon_{\mathrm{pjc} 9698}
$$

$\mathrm{S}_{\mathrm{pjc} 9698}$ is the exit rate in occupation $p$ in firm $j$ located in city $c$, measured over a three-year window (1996-98). This model is slightly different from the model estimated on worker data as shown by comparing equations (5) and (7). Indeed, we do not have a panel of firms, so that we cannot introduce labor market fixed effects. The identifying assumption underlying a causal interpretation of $b_{p}$ is therefore somewhat stronger: one has to assume that unobservable variables that drive the level of turnover in firms (as of 1996-98) are not correlated with the local labor market initial skill mix. Instead, the assumption for a causal interpretation of estimates in (5) is that changes in turnover are not driven by unobserved factors correlated with the initial skill mix. Estimates of $b_{p}$ are in table 6 . They are not statistically significant, whatever the occupation. They allow us to reject strong increases in turnover (although the estimates for blue-collar workers are somewhat imprecise): this is consistent with table 3 . We do not find evidence that job insecurity decreases (as we did in table 3); note that this may be partly due to a lack of power.

This first pass on the firm data confirms the adoption pattern found with worker data, and that job instability did not increase as a consequence of IT adoption. But the true value of the firm data is to uncover some of the mechanisms through which firms adapt their workforce to the skill requirements associated with IT. In what follows, we adopt the same approach as Behaghel et al. (2011) in order to assess whether firm human resources strategies can explain the absence of increase in job instability. Skill-biased technical change is often documented by changes in the occupational structure of adopting firms, estimating the following model on firm data:

$$
\Delta S_{j c p}=x_{j c} \beta_{p}+I T_{j c} \delta_{p}+\varepsilon_{j c p}
$$


where $\Delta S_{j c p}$ is the change in the share of occupation $p$ in firms $j$ located in local labor market c. Typically, one expects positive $\delta_{p}$ in skilled occupations, and negative ones in less skilled ones. Following Behaghel et al. (2011), this upward shift can be approximately decomposed into two parts: changes in the occupational structure that result from the entry and exit of workers (which we denote $\Delta \widetilde{S}_{j c p}$ ) and changes that result from internal promotions and demotions (which we denote $\Delta \hat{S}_{j c p}$ ). Holding the occupational structure constant, another channel is to acquire new skills through the addition of fresh workers in a given occupation. Following the literature on worker flows (see in particular Davis and Haltiwanger, 1999), this can be measured as excess turnover, $e t_{j c p}$, i.e. flows in excess of the minimum worker flows needed to adjust the size of occupation $p$ in firm $j$. Last, we consider training $T_{j c p}$, measured in two ways: number of trainees per 100 workers, and training hours per worker. To summarize, and following Behaghel et al. (2011), firm strategies associated with IT-based technical change can be analyzed by weighting "internal labor market responses" (promotions and training) estimated by:

$$
\Delta \hat{S}_{j c p}=x_{j c} \hat{\beta}_{p}+I T_{j c} \hat{\delta}_{p}+\hat{\varepsilon}_{j c p}
$$

and

$$
T_{j c p}=x_{j c} \beta_{L}^{T}+I T_{j c} \delta_{p}^{T}+\varepsilon_{j c p}^{T}
$$

against "external labor market responses" (hiring workers in higher skill groups or relying on excess turnover), as estimated by

$$
\Delta \widetilde{S}_{j c p}=x_{j c} \widetilde{\beta}_{p}+I T_{j c} \widetilde{\delta}_{p}+\widetilde{\varepsilon}_{j c p}
$$

and

$$
e t_{j c p}=x_{j c} \beta_{L}^{e t}+I T_{j c} \delta_{p}^{e t}+\varepsilon_{j c p}^{e t}
$$

When estimating equations (8)-(12), Behaghel et al. (2011) acknowledge that their estimates should not necessarily be interpreted causally. Indeed, the endogeneity of the technology adoption variable remains an issue. Here, the variations provided by skill mix differences across local labor market and the strong and significant results obtained from estimating equation (6) suggest to use $E d u c_{c 0}$ as an instrument for $I T_{j c}$. The exclusion restriction is that 
unobserved determinants of firms' human resources policy (as of 1996-98) should not be correlated with the skill mix of the local labor market (as of 1975). While this restriction is not above criticism, it is weaker than assuming the exogeneity of $I T_{j c}$. The 2SLS results are given in table $7 .{ }^{18}$ The first panel shows the overall impact of IT adoption on the firms' occupational structure: the share of managers and professionals increases significantly at the expense of lower occupations. The increase is sizeable: a 4.7 percentage point increase. This is more than the OLS estimate (1.3 pp) reported in Behaghel et al. (2011). This can be due to measurement error (if the internet/intranet variable is an imperfect proxy for the firm's technology level) or to downward biases affecting the OLS estimates. Note however that the 2SLS effect is imprecisely estimated, so that the difference between the two estimations should not be overstated. Panels B to F show that internal labor market responses are able to account for most of the skills upgrading. The upward shift in the occupational structure can almost fully be explained by higher promotion rates (panel B), while worker flows explain at most $25 \%$ of the change (panel C). There is no significant increase in excess turnover (panel D). Conversely, though they are not precisely estimated, effects on training measures tend to be positive (panels E and F), and are statistically significant for clerks and blue collars. ${ }^{19}$ To sum up, there is little evidence that firms adopting IT relied upon the external labor market to upgrade their workforce, while there is consistent evidence that they used internal labor market mechanisms, such as training and promotions. This could explain the absence of increase in job instability found on the worker data. ${ }^{20}$

\section{Conclusion}

Based on two different sources on IT use, we find that workers and firms located in more educated labor markets tend to adopt IT faster, even after controlling for the worker's individual education level. This is consistent with models of endogenous adoption of new technologies. However, workers do not experience less job stability, and firms do not display

\footnotetext{
${ }^{18}$ Estimating equations (8)-(12) by 2SLS rather than estimating the corresponding reduced form as for equations (5) and (7) allows a direct comparison with the OLS results displayed in Behaghel et al. (2011). It would be possible to estimate the 2SLS models corresponding to equations (4)-(5) and (6)-(7). For equations (6)-(7), the results are unchanged: no significant effect. Equations (4)-(5) would require to use two-sample 2SLS, and a careful interpretation of the endogenous variable of interest. Indeed, our identification strategy does not allow to isolate the direct effect of the worker being more likely to use computers from the "contextual" effect of having co-workers in the same firms (or other workers in nearby firms) using computers more intensively. In that sense, the estimation keeps a reduced form character: we prefer to keep this transparent by estimating only reduced form equations.

${ }^{19}$ These estimates are qualitatively similar to the OLS results in Behaghel et al. (2011), but quantitatively larger.

${ }^{20} \mathrm{We}$ perform various robustness checks on table 7. In particular, using a polynomial in Educ $c_{c 0}$ as instruments or adding local labor market controls (density of the labor supply or regional dummies) does not change the results qualitatively (see tables A2 and A3 in the appendix).
} 
larger workers' flows. This is at odds with a Schumpeterian model of creative destruction, or with "post-Fordist" theories. Building on previous work (and improving it with an arguably exogenous source of variation), we show that these findings can be explained by French firms' human resource strategies in which internal labor markets' mechanisms, namely firmprovided training and internal promotions, still play a large role.

These results have to be interpreted within the French context. First, it should be noted that the period under study is a period of rising job instability (more clearly perhaps than in other countries). If the adoption of IT is not the driving force, this trend remains to be explained. Changes in labor market regulation (in particular, the more frequent use of fixed-term contracts) is a possible explanation (see the discussion, e.g., by Cahuc and Postel-Vinay, 2002). The second point to stress is that the persistence of internal labor market in France may be more the exception than the rule. By international standards, France is indeed still characterized by strict employment protection legislation (Venn, 2009): firms perhaps rely on internal adjustments because going on the external labour market is simply too costly. LFS data, provided that workers can be located, allow to replicate the main analyses of this paper; we believe that similar work using local labor market as a source of variation in other countries could yield useful insights. 


\section{References}

Acemoglu, D., 2007, "Equilibrium Bias of Technology, Econometrica, September 2007, volume 75, pp. 1371-1410.

Askenazy P. and Moreno-Galbis E., 2007, "The Impact of Technological and Organizational Changes on Labor Flows. Evidence on French Establishments", Labour, 21(2), pp. 265-301.

Aubert P, Caroli E. and Roger M, 2006a, " New Technologies, Organisation and Age: FirmLevel Evidence", Economic Journal, 116, pp. 73-93.

Autor D., Levy F. and Murnane R, 2003 “The Skill content of Recent Technological Change: An Empirical Exploration”, Quarterly Journal of Economics, pp. 1279-1383.

Bauer T. and Bender S., 2004, "Technological Change, Organizational Change and Job Turnover", Labour Economics, 11(3), pp. 265-91.

Beaudry P., Doms M. and Lewis E. (2010) "Should the Personal Computer Be Considered a Technological Revolution? Evidence from U.S. Metropolitan Areas", Journal of Political Economy, 118(5): 988-1036

Beaudry P., Doms M. and Lewis E., 2008, "Should the PC be Considered a Technological Revolution? City Level Evidence from 1980-2000”, mimeo.

Behaghel L., Caroli E. and Walkowiak E., 2011; "Information and Communication Technologies and Skill Upgrading: the Role of Internal vs External Labour Markets", Oxford economic papers, forthcoming.

Bertrand M., 2004 "From The Invisible Handshake To The Invisible Hand? How Import Competition Changes The Employment Relationship," Journal of Labor Economics, 22(4), 723-765.

Bloom N. and Van Reenen J., 2010, "Why do management practices differ across firms and countries?", Journal of Economic Perspectives, 24 (1), 203-224

Bloom N, Draca M. and Van Reenen J. (2010) “Trade Induced Technical Change: The Impact of Chinese Imports on Innovation, Diffusion and Productivity", mimeo

Cahuc P. and F. Postel-Vinay (2002) "Temporary jobs, employment protection and labor market performance", Labour Economics, 6: 63-91.

Caroli E., 2007, "Internal versus external labour flexibility: the role of knowledge codification”, National Institute Economic Review, n²01, pp. 107-118.

Caselli, F., 1999, “Technological Revolutions.” American Economic Review, 89:1, pp. 78102.

Davis, S.J., and Haltiwanger, J., 1999, “Gross job flows", in Ashenfelter, O., Card, D. (eds), Handbook of Labor Economics, 3b. North-Holland, Amsterdam, 2711- 805.

DiPrete A., Goux D. and Maurin E., 2002, "Internal Labor Markets and Earnings Trajectories in the Post-Fordist Economy: An Analysis of Recent Trends", Social Science Research, 31, pp. 175-96.

Farber, H., 20010, "Job Loss and the Decline in Job Security in the United States", in Labor in the New Economy, Katharine G. Abraham, James R. Spletzer, and Michael Harper (eds), pp. $223-262$, University of Chicago Press. 
Farber, H., 2007, "Is the Company Man an Anachronism? Trends in Long Term Employment in the U.S., 1973-2006", in S. Danziger and C. Rouse eds, The Price of Independence, NewYork, Russell Sage.

Givord, P. and Maurin E., 2004, "Changes in Job Security and their Causes: An Empirical Analysis for France, 1982-2002”, European Economic Review, 48, pp. 595-615.

Goldin, C. and Sokoloff K., 1984, "The Relative Productivity Hypothesis of Industrialization: The American Case, 1820 to 1850." Quarterly Journal of Economics, 99 (August): pp. 461488.

Habakkuk, H.J. (1962). American and British Technology in the Nineteenth Century. Cambridge: Cambridge University Press.

Gottschalk P. and R. Moffitt, "Changes in Job Instability and Insecurity Using Monthly Survey Data" Journal of Labor Economics, Vol. 17, No. 4, Part 2, pp. S91-S126.

Lewis, E, 2005, "Immigration, Skill Mix, and the Choice of Technique", Federal Reserve Bank of Philadelphia Working Paper \#05-08, May 2005.

Marsden D., 1999, A Theory of Employment Systems: Micro-foundations of social diversity, Oxford University Press.

Mincer J., 1989, "Human Capital Responses to Technological Change in the Labor Market", NBER Working Paper, $n^{\circ} 3207$.

Moretti E., 2004, "Estimating the social return to higher education: evidence from longitudinal and repeated cross-sectional data", Journal of Econometrics 121 (2004) 175 212.

Neumark D. and Reed D., 2004, "Employment Relationships in the New Economy", Labour Economics, 11(1), pp. 1-31.

Reich M., 2001, The Future of Success, Alfred A. Knopf, New-York.

Stevens A.H., 2005, "The more things change, the more they stay the same: Trends in LongTerm Employment in the United States, 1969-2002", NBER Working Paper 11878.

Valletta R. (1999), “Declining job security”, Journal of Labor Economics, 4(17); S170-197.

Venn, D., 2009 "Legislation, collective bargaining and enforcement: updating the OECD employment protection indicators”, OECD-ELSA Working Paper.

Wooldridge J., 2002, Econometric Analysis of Cross Section and Panel Data, MIT Press, Cambrige. 
Table 1: Initial skill mix, computer and the Internet use in 1998

\begin{tabular}{|c|c|c|c|}
\hline & Spe 1 & Spe 2 & Spe 3 \\
\hline & \multicolumn{3}{|c|}{ A. Computer use (x 100) } \\
\hline Skill mix in 1975 & $\begin{array}{c}147,0 * * * \\
(0,8)\end{array}$ & $\begin{array}{c}123,9^{* * * *} \\
(1,1)\end{array}$ & $\begin{array}{c}119,4 * * * \\
(1,2)\end{array}$ \\
\hline \multirow[t]{2}{*}{ Obs. } & 63996 & 63996 & 63996 \\
\hline & \multicolumn{3}{|c|}{ B. Internet use (x 100) } \\
\hline Skill mix in 1975 & $\begin{array}{c}81,2^{* * * *} \\
(0,3)\end{array}$ & $\begin{array}{c}69,8^{* * *} \\
(0,4)\end{array}$ & $\begin{array}{c}62,6^{* * * *} \\
(0,4)\end{array}$ \\
\hline Obs. & 63996 & 63996 & 63996 \\
\hline \multicolumn{4}{|l|}{ Additional controls } \\
\hline Individual characteristics & No & Yes & Yes \\
\hline Local characteristics & No & No & Yes \\
\hline
\end{tabular}

Levels of significance: $\quad *: 10 \% \quad * *: 5 \% \quad * * *: 1 \%$

SAMPLE: individuals aged 20 to 59

NOTE: A separate OLS regression is run for each panel and each specification. Regressions include individual controls: sex, age (5-year dummies), tenure (year dummies for tenure between 1 and 4 years and 5-year dummies for tenure over 4 years), diploma (6 dummies), socio-professional category (6 dummies), sector (16 dummies), size of the establishment (5 dummies), size of the city (9 dummies); and local labor market controls: active population density in 1975 (simple and squared), share of the labor force aged 40 and more in 1975

READING: a $10 \mathrm{pp}$ increase in the share of high-school graduates in 1975 increases the use of computers in 1998 by $14.7 \mathrm{pp}$

SOURCES: Population census (1975), Labor Force Surveys (1998), Working Conditions survey (1998) 
Table 2: Initial skill mix, computer and Internet use in 1998 by subgroups

\begin{tabular}{|c|c|c|c|c|c|c|c|c|}
\hline & All & $\begin{array}{c}\text { HS } \\
\text { graduates }\end{array}$ & HS dropouts & Men & Women & $\begin{array}{c}<30 \text { years } \\
\text { old }\end{array}$ & $\begin{array}{c}30-49 \text { years } \\
\text { old }\end{array}$ & $\begin{array}{c}>50 \text { years } \\
\text { old }\end{array}$ \\
\hline & \multicolumn{8}{|c|}{ A. Computer use (x 100) } \\
\hline Skill mix in 1975 & $\begin{array}{c}123,9 * * * \\
(1,1)\end{array}$ & $\begin{array}{c}108,8 * * * \\
(1,7)\end{array}$ & $\begin{array}{c}136,3 * * * \\
(1,5)\end{array}$ & $\begin{array}{c}125,6 * * * \\
(1,5)\end{array}$ & $\begin{array}{c}121,8^{* * *} \\
(1,6)\end{array}$ & $\begin{array}{c}117,9 * * * \\
(2,4)\end{array}$ & $\begin{array}{c}124,5 * * * \\
(1,4)\end{array}$ & $\begin{array}{c}128,6 * * * \\
(2,6)\end{array}$ \\
\hline \multirow[t]{2}{*}{ Obs. } & 63996 & 23864 & 40132 & 34856 & 29140 & 12340 & 39296 & 12360 \\
\hline & \multicolumn{8}{|c|}{ B. Internet use (x 100) } \\
\hline Skill mix in 1975 & $\begin{array}{c}69,8^{* * *} \\
(0,4)\end{array}$ & $\begin{array}{c}73,6^{* * *} \\
(0,6)\end{array}$ & $\begin{array}{c}66,9^{* * *} \\
(0,5)\end{array}$ & $\begin{array}{c}69,0 * * * \\
(0,5)\end{array}$ & $\begin{array}{c}70,7 * * * \\
(0,6)\end{array}$ & $\begin{array}{c}68,8 * * * \\
(0,9)\end{array}$ & $\begin{array}{c}69,4^{* * *} \\
(0,5)\end{array}$ & $\begin{array}{c}71,9^{* * *} \\
(0,9)\end{array}$ \\
\hline Obs. & 63996 & 23864 & 40132 & 34856 & 29140 & 12340 & 39296 & 12360 \\
\hline
\end{tabular}

Levels of significance: $\quad *: 10 \% \quad * *: 5 \% \quad * * *: 1 \%$

SAMPLE: individuals aged 20 to 59

NOTE: A separate OLS regression is run for each panel and each subgroup. Specification 2 of table 1 is used. Regressions include individual controls: sex, age (5-year dummies), tenure (year dummies for tenure between 1 and 4 years and 5-year dummies for tenure over 4 years), diploma (6 dummies), socio-professional category (6 dummies), sector (16 dummies), size of the establishment (5 dummies), size of the city (9 dummies)

READING: a $10 \mathrm{pp}$ increase in the share of high-school graduates in 1975 increases the use of computers in 1998 by $12.4 \mathrm{pp}$

SOURCES: Population census (1975), Labor Force Surveys (1998), Working Conditions survey (1998) 
Table 3: Initial skill mix, job insecurity and job instability (1975-2002)

\begin{tabular}{|c|c|c|c|c|}
\hline & Spe 1 & Spe 2 & Spe 3 & Spe 4 \\
\hline & \multicolumn{4}{|c|}{ A. Transitions to non employment (x 100) } \\
\hline Skill mix in $1975 *$ trend & $\begin{array}{l}-0,02 \\
(0,07)\end{array}$ & $\begin{array}{c}-0,25^{* *} \\
(0,11)\end{array}$ & $\begin{array}{c}-0,25^{* *} \\
(0,11)\end{array}$ & $\begin{array}{c}-0,44 * * * \\
(0,10)\end{array}$ \\
\hline \multirow[t]{2}{*}{ Obs. } & 894869 & 894869 & 894869 & 894869 \\
\hline & \multicolumn{4}{|c|}{ B. Transitions to unemployment (x 100) } \\
\hline Skill mix in $1975 *$ trend & $\begin{array}{l}-0,16^{*} \\
(0,09)\end{array}$ & $\begin{array}{l}-0,15^{*} \\
(0,08)\end{array}$ & $\begin{array}{l}-0,15^{*} \\
(0,08)\end{array}$ & $\begin{array}{c}-0,28 * * * \\
(0,09)\end{array}$ \\
\hline \multirow[t]{2}{*}{ Obs. } & 894869 & 894869 & 894869 & 894869 \\
\hline & \multicolumn{4}{|c|}{ C. Job-to-job transitions (x 100) } \\
\hline Skill mix in $1975 *$ trend & $\begin{array}{c}-0,59 * * * \\
(0,15)\end{array}$ & $\begin{array}{c}0,00 \\
(0,09)\end{array}$ & $\begin{array}{c}0,00 \\
(0,09)\end{array}$ & $\begin{array}{l}-0,08 \\
(0,10)\end{array}$ \\
\hline Obs. & 894869 & 894869 & 894869 & 894869 \\
\hline \multicolumn{5}{|l|}{ Additional controls } \\
\hline Individual characteristics & No & Yes & Yes & Yes \\
\hline Skill mix in $1975 *$ GDP & No & No & Yes & Yes \\
\hline Local characteristics & No & No & No & Yes \\
\hline
\end{tabular}

Levels of significance: $\quad *: 10 \% \quad * *: 5 \% \quad * * *: 1 \%$

SAMPLE: individuals aged 20 to 59 holding a job each year (to compute transitions to non employment, unemployment and to another job the year after)

NOTE: Robust standard errors are clustered at the local labor market level. A separate fixed-effect regression is run for each panel and each specification. Regressions include year dummies, individual controls: sex, age (5year dummies), tenure (year dummies for tenure between 1 and 4 years and 5-year dummies for tenure over 4 years), diploma (6 dummies), socio-professional category (6 dummies), sector (16 dummies), size of the establishment (5 dummies), size of the city (9 dummies); individual controls interacted with a trend; the share of high-school graduates in 1975 interacted with GDP; and local labor market controls interacted with a trend: active population density in 1975 (simple and squared), share of the labor force aged 40 and more in 1975

READING: a $10 \mathrm{pp}$ increase in the share of high-school graduates in 1975 reduces transitions to unemployment between 1975 and 2002 by 0.02 pp per year

SOURCES: Population census (1975), Labor Force Surveys (1975-2002) 
Table 4: Initial skill mix, job insecurity and job instability by subgroups (1975-2002)

\begin{tabular}{|c|c|c|c|c|c|c|c|c|}
\hline & All & $\begin{array}{c}\text { HS } \\
\text { graduates }\end{array}$ & HS dropouts & Men & Women & $\begin{array}{c}<30 \text { years } \\
\text { old }\end{array}$ & $\begin{array}{c}30-49 \text { years } \\
\text { old }\end{array}$ & $\begin{array}{c}>50 \text { years } \\
\text { old }\end{array}$ \\
\hline & \multicolumn{8}{|c|}{ A. Transitions to non employment (x 100) } \\
\hline Skill mix in $1975 * \mathrm{t}$ & $\begin{array}{c}-0,25^{* *} \\
(0,11)\end{array}$ & $\begin{array}{c}-0,35 * * * \\
(0,12)\end{array}$ & $\begin{array}{c}-0,30^{* *} \\
(0,14)\end{array}$ & $\begin{array}{l}-0,19 * \\
(0,10)\end{array}$ & $\begin{array}{c}-0,42 * * \\
(0,19)\end{array}$ & $\begin{array}{c}-0,60 * * \\
(0,29)\end{array}$ & $\begin{array}{l}-0,15 \\
(0,10)\end{array}$ & $\begin{array}{l}-0,12 \\
(0,16)\end{array}$ \\
\hline \multirow[t]{2}{*}{ Obs. } & 894869 & 245677 & 649192 & 512939 & 381930 & 180856 & 530911 & 183102 \\
\hline & \multicolumn{8}{|c|}{ B. Transitions to unemployment (x 100) } \\
\hline Skill mix in $1975 * \mathrm{t}$ & $\begin{array}{l}-0,15^{*} \\
(0,08)\end{array}$ & $\begin{array}{l}-0,09 \\
(0,09)\end{array}$ & $\begin{array}{c}-0,23 * * \\
(0,10)\end{array}$ & $\begin{array}{l}-0,15 \\
(0,10)\end{array}$ & $\begin{array}{l}-0,15 \\
(0,11)\end{array}$ & $\begin{array}{c}-0,54 * * * \\
(0,20)\end{array}$ & $\begin{array}{l}-0,10 \\
(0,09)\end{array}$ & $\begin{array}{c}0,03 \\
(0,09)\end{array}$ \\
\hline \multirow[t]{2}{*}{ Obs. } & 894869 & 245677 & 649192 & 512939 & 381930 & 180856 & 530911 & 183102 \\
\hline & \multicolumn{8}{|c|}{ C. Job-to-job transitions (x 100) } \\
\hline Skill mix in $1975 * \mathrm{t}$ & $\begin{array}{c}0,00 \\
(0,09)\end{array}$ & $\begin{array}{l}-0,04 \\
(0,14)\end{array}$ & $\begin{array}{l}-0,04 \\
(0,10)\end{array}$ & $\begin{array}{l}-0,06 \\
(0,12)\end{array}$ & $\begin{array}{c}0,11 \\
(0,11)\end{array}$ & $\begin{array}{c}0,29 \\
(0,21)\end{array}$ & $\begin{array}{l}-0,07 \\
(0,12)\end{array}$ & $\begin{array}{l}-0,04 \\
(0,16)\end{array}$ \\
\hline Obs. & 894869 & 245677 & 649192 & 512939 & 381930 & 180856 & 530911 & 183102 \\
\hline
\end{tabular}

Levels of significance: $\quad *: 10 \% \quad * *: 5 \% \quad * * *: 1 \%$

SAMPLE: individuals aged 20 to 59 holding a job each year (to compute transitions to non employment, unemployment and to another job the year after)

NOTE: Robust standard errors are clustered at the local labor market level. A separate fixed-effect regression is run for each panel and each subgroup. Specification 3 of table 3 is used. Regressions include year dummies, individual controls: sex, age (5-year dummies), tenure (year dummies for tenure between 1 and 4 years and 5year dummies for tenure over 4 years), diploma (6 dummies), socio-professional category (6 dummies), sector (16 dummies), size of the establishment (5 dummies), size of the city (9 dummies); individual controls interacted with a trend; the share of high-school graduates in 1975 interacted with GDP

READING: a $10 \mathrm{pp}$ increase in the share of high-school graduates in 1975 reduces transitions to unemployment between 1975 and 2002 by 0.02 pp per year

SOURCES: Population census (1975), Labor Force Surveys (1975-2002) 
Table 5: Local skill mix in 1975 and IT adoption by firms in 1998

\begin{tabular}{|c|c|c|c|c|c|c|c|c|}
\hline \multirow[b]{2}{*}{ Edu_c0>median } & \multicolumn{8}{|c|}{ Dependent variable: Internet/intranet } \\
\hline & $\begin{array}{c}0.189 * \star * \\
(0.030)\end{array}$ & $\begin{array}{l}0.159 * \star \star \\
(0.030)\end{array}$ & $\begin{array}{l}0.122^{\star \star \star} \\
(0.032)\end{array}$ & $\begin{array}{c}0.096^{\star \star \star} \\
(0.031)\end{array}$ & & & & \\
\hline Edu_c0 & & & & & $\begin{array}{c}2.830 * \star \star \\
(1.016)\end{array}$ & $\begin{array}{l}2.619 \star \star \\
(1.114)\end{array}$ & $\begin{array}{c}1.975^{\star} \\
(1.168)\end{array}$ & $\begin{array}{c}1.612 \\
(1.288)\end{array}$ \\
\hline$(\text { Edu_c0 })^{2}$ & & & & & $\begin{array}{c}-2.157 \\
(2.499)\end{array}$ & $\begin{array}{c}-2.232 \\
(2.860)\end{array}$ & $\begin{array}{l}-1.179 \\
(2.912)\end{array}$ & $\begin{array}{l}-0.136 \\
(3.270)\end{array}$ \\
\hline Number of plants & 1,109 & 1,109 & 1,109 & 1,109 & 1,109 & 1,109 & 1,109 & 1,109 \\
\hline $\mathrm{R}^{2}$ & 0.040 & 0.124 & 0.129 & 0.147 & 0.054 & 0.133 & 0.136 & 0.153 \\
\hline Firm controls & yes & yes & yes & yes & yes & yes & yes & yes \\
\hline Labor market density & no & no & yes & yes & no & no & yes & yes \\
\hline Region dummies & no & no & no & yes & no & no & no & yes \\
\hline F-stat instruments & 39.22 & 27.50 & 14.90 & 9.365 & 110.3 & 29.45 & 16.27 & 10.32 \\
\hline
\end{tabular}

Levels of significance: $\quad *: 10 \% \quad * *: 5 \% \quad * * *: 1 \%$

NOTE: Linear probability model for using the Internet or an Intranet; robust standard errors clustered at the local labor market level. Firm controls are: plant size (dummy variable for plants with more than 200 employees); indicators for multi-establishment firms, public sector companies, listed companies, presence of union delegates; share of women in the workforce, part-time work (dummy variable for firms with more than 5\% of workers being part-time) and 15 sector dummies.

NOTE: The probability that a firm uses the Internet or an Intranet in 1998 increases by 18.9 percentage points if the firm is located in a local labor market that had above median skill mix in 1975.

NoTE: Population census (1975); REPONSE firm survey. 
Table 6: Initial skill mix and worker exit rates from firms (1996-98)

\begin{tabular}{|c|c|c|c|c|c|c|c|c|}
\hline & $\begin{array}{l}\text { Managers and } \\
\text { professionals }\end{array}$ & $\begin{array}{c}\text { Technicians } \\
\text { and } \\
\text { supervisors }\end{array}$ & Clerks & Blue collars & $\begin{array}{l}\text { Managers and } \\
\text { professionals }\end{array}$ & $\begin{array}{c}\text { Technicians } \\
\text { and } \\
\text { supervisors }\end{array}$ & Clerks & Blue collars \\
\hline & \multicolumn{4}{|c|}{ A. Instrument: 1(Educ_c0>median) } & \multicolumn{4}{|c|}{ B. Instruments: Educ_c0, $(\text { Educ_c0 })^{2}$} \\
\hline \multirow[t]{2}{*}{ Intemet/Intranet } & -0.09 & 0.16 & 0.20 & 0.89 & -0.08 & 0.56 & 0.54 & 1.25 \\
\hline & $(0.10)$ & $(0.13)$ & $(0.19)$ & $(0.60)$ & $(0.20)$ & $(0.41)$ & $(0.34)$ & $(0.86)$ \\
\hline Firm controls & yes & yes & yes & yes & yes & yes & yes & yes \\
\hline Labor market density & no & no & no & no & yes & yes & yes & yes \\
\hline Region dummies & no & no & no & no & yes & yes & yes & yes \\
\hline $\mathrm{N}$ & 1085 & 1090 & 1099 & 1041 & 1085 & 1090 & 1099 & 1041 \\
\hline Average tumover & 0.15 & 0.15 & 0.33 & 0.28 & 0.15 & 0.15 & 0.33 & 0.28 \\
\hline
\end{tabular}

Levels of significance: $\quad *: 10 \% \quad * *: 5 \% \quad * * *: 1 \%$

NOTE: 2SLS models. The dependent variable is the worker exit rate, computed separately in four occupation groups. Instrument for Internet-Intranet: indicator variable for local labor markets with above median share of high-school graduates (as of 1975) in columns 1-4; quadratic in the share of high-school graduates (as of 1975) in columns 5-8. The corresponding first stage equations are displayed in table 5.

Firm controls are: plant size (dummy variable for plants with more than 200 employees); indicators for multiestablishment firms, public sector companies, listed companies, presence of union delegates; share of women in the workforce, part-time work (dummy variable for firms with more than $5 \%$ of workers being part-time) and 15 sector dummies.

NOTE: The adoption of Internet/Intranet leads to a 3 percentage point decrease in the exit rate of blue collar workers (not statistically significant).

NOTE: Population census (1975); REPONSE survey, EMMO, DMMO, ESE and 24-83. 
Table 7: IT adoption and skill upgrading channels: 2SLS estimates

\begin{tabular}{|c|c|c|c|c|}
\hline & $\begin{array}{l}\text { Managers and } \\
\text { professionals }\end{array}$ & $\begin{array}{c}\text { Technicians and } \\
\text { supervisors }\end{array}$ & Clerks & Blue collars \\
\hline & \multicolumn{4}{|c|}{ A. Overall changes in the occupational structure } \\
\hline \multirow[t]{2}{*}{ Internet/Intranet } & $4.73^{* * *}$ & -0.49 & -2.28 & -1.96 \\
\hline & $(1.23)$ & $(1.55)$ & $(1.49)$ & $(1.80)$ \\
\hline \multirow[t]{2}{*}{ Obs } & 1,109 & 1,109 & 1,109 & 1,109 \\
\hline & \multicolumn{4}{|c|}{ B. Intemal movements } \\
\hline \multirow[t]{2}{*}{ Internet/Intranet } & $4.02^{* \star *}$ & 0.43 & -2.74 & -1.71 \\
\hline & $(1.28)$ & $(1.71)$ & $(1.68)$ & $(1.78)$ \\
\hline \multirow[t]{2}{*}{ Obs } & 1,109 & 1,109 & 1,109 & 1,109 \\
\hline & \multicolumn{4}{|c|}{ C. External movements } \\
\hline \multirow[t]{2}{*}{ Internet/Intranet } & 1.06 & -0.59 & 0.48 & -0.95 \\
\hline & $(0.98)$ & $(1.30)$ & $(1.09)$ & $(1.39)$ \\
\hline \multirow[t]{2}{*}{ Obs } & 1,109 & 1,109 & 1,109 & 1,109 \\
\hline & \multicolumn{4}{|c|}{ D. Excess tumover } \\
\hline \multirow[t]{2}{*}{ Internet/Intranet } & -20.67 & 25.85 & 37.95 & 156.79 \\
\hline & $(18.71)$ & $(26.34)$ & (38.01) & $(114.22)$ \\
\hline \multirow[t]{2}{*}{ Obs } & 1,085 & 1,090 & 1,099 & 1,041 \\
\hline & \multicolumn{4}{|c|}{ E. Number of trainees (per 100 workers) } \\
\hline \multirow[t]{2}{*}{ Internet/Intranet } & 11.60 & $51.01^{*}$ & $27.07^{\star \star}$ & $50.73^{\star \star}$ \\
\hline & $(13.08)$ & $(27.27)$ & (13.12) & $(20.82)$ \\
\hline \multirow[t]{2}{*}{ Obs } & 1,092 & 1,047 & 1,082 & 905 \\
\hline & \multicolumn{4}{|c|}{ F. Training hours per worker } \\
\hline \multirow[t]{2}{*}{ Internet/Intranet } & 2.78 & 6.11 & $9.79 \star \star$ & $10.01^{\star \star}$ \\
\hline & $(6.55)$ & $(6.84)$ & $(4.68)$ & $(4.15)$ \\
\hline Obs & 1,090 & 1,037 & 1,078 & 903 \\
\hline
\end{tabular}

Levels of significance: $\quad *: 10 \% \quad * *: 5 \% \quad * * *: 1 \%$

NOTE: A separate 2SLS regression is run in each panel and for each occupational category. Each regression includes controls for plant size (dummy variable for plants with more than 200 employees), being located on a labour market whose density is higher than the median, multi-establishment firms, public sector companies, listed companies, presence of union delegates, share of women in the labour force, part-time work (dummy variable for firms with more than $5 \%$ of workers being part-time) and 15 sectors. The instrument for the InternetIntranet variable is an indicator variable for local labor markets with above median share of high-school graduates (as of 1975). The corresponding first stage is in table 5. 
READING: The adoption of Internet/Intranet leads to a 4.7 percentage point increase in the share of managers and professionals.

NoTE: Population census (1975); REPONSE survey, EMMO, DMMO, ESE and 24-83. 
Figure 1: Share of high-school graduates and above in 1975

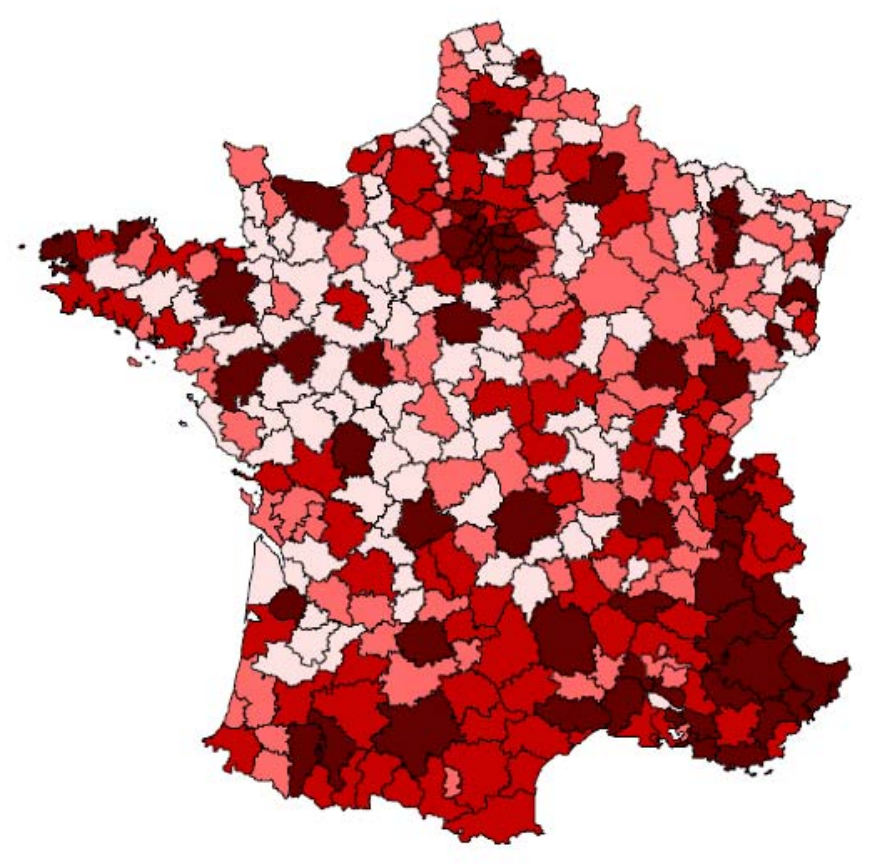

\section{SHARE34}

\begin{tabular}{|l|l|}
\hline & $0.07-0.1$ \\
& $0.1-0.12$ \\
$0.12-0.15$ \\
$0.15-0.36$
\end{tabular}

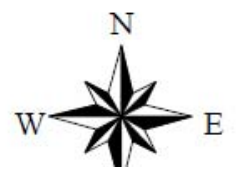


Figure 2: Population density in 1975
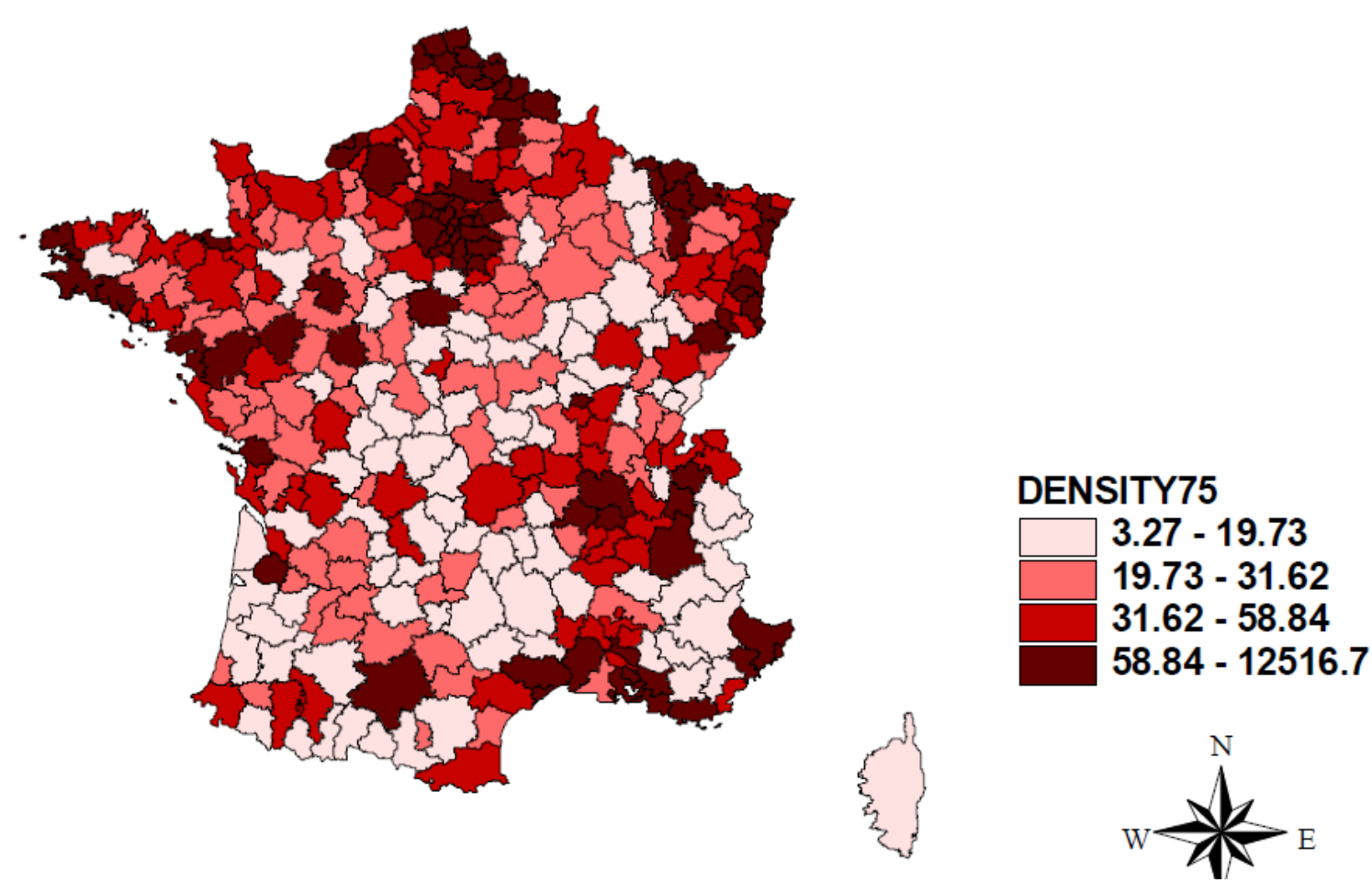
Figure 3: Share of high-school graduates and above in 1999

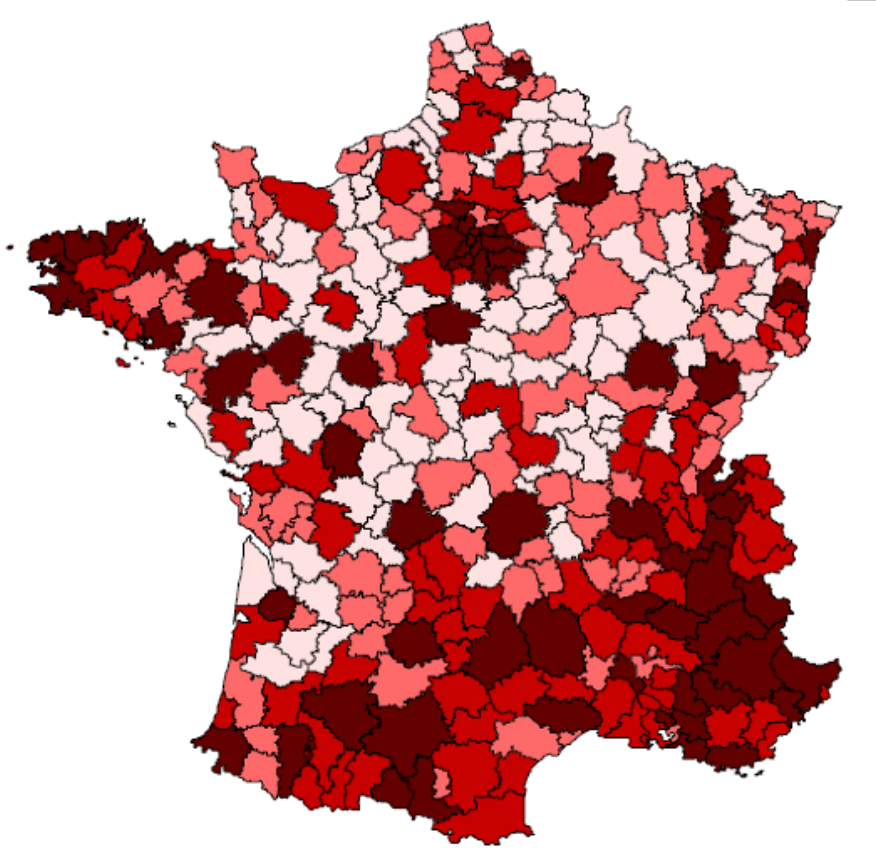

SHARE34_99

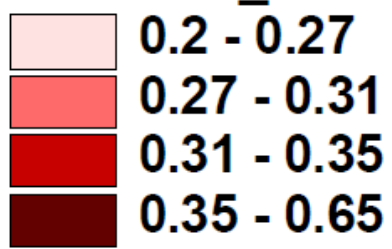

1

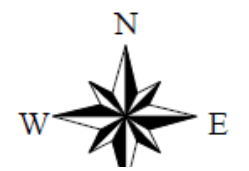


Figure 4: Adoption of PCs and the Internet (1987-2005)
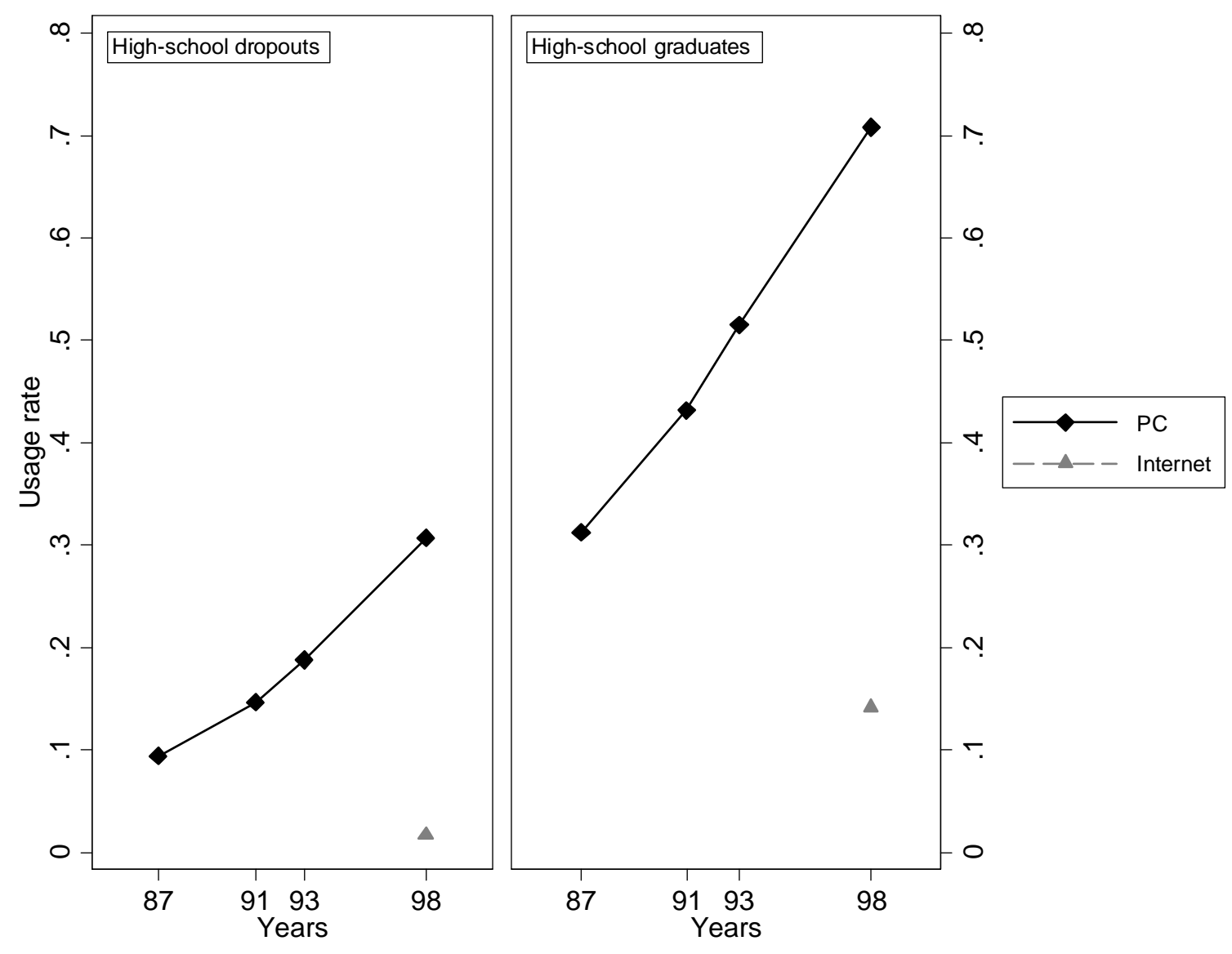
Figure 5: Transitions from employment

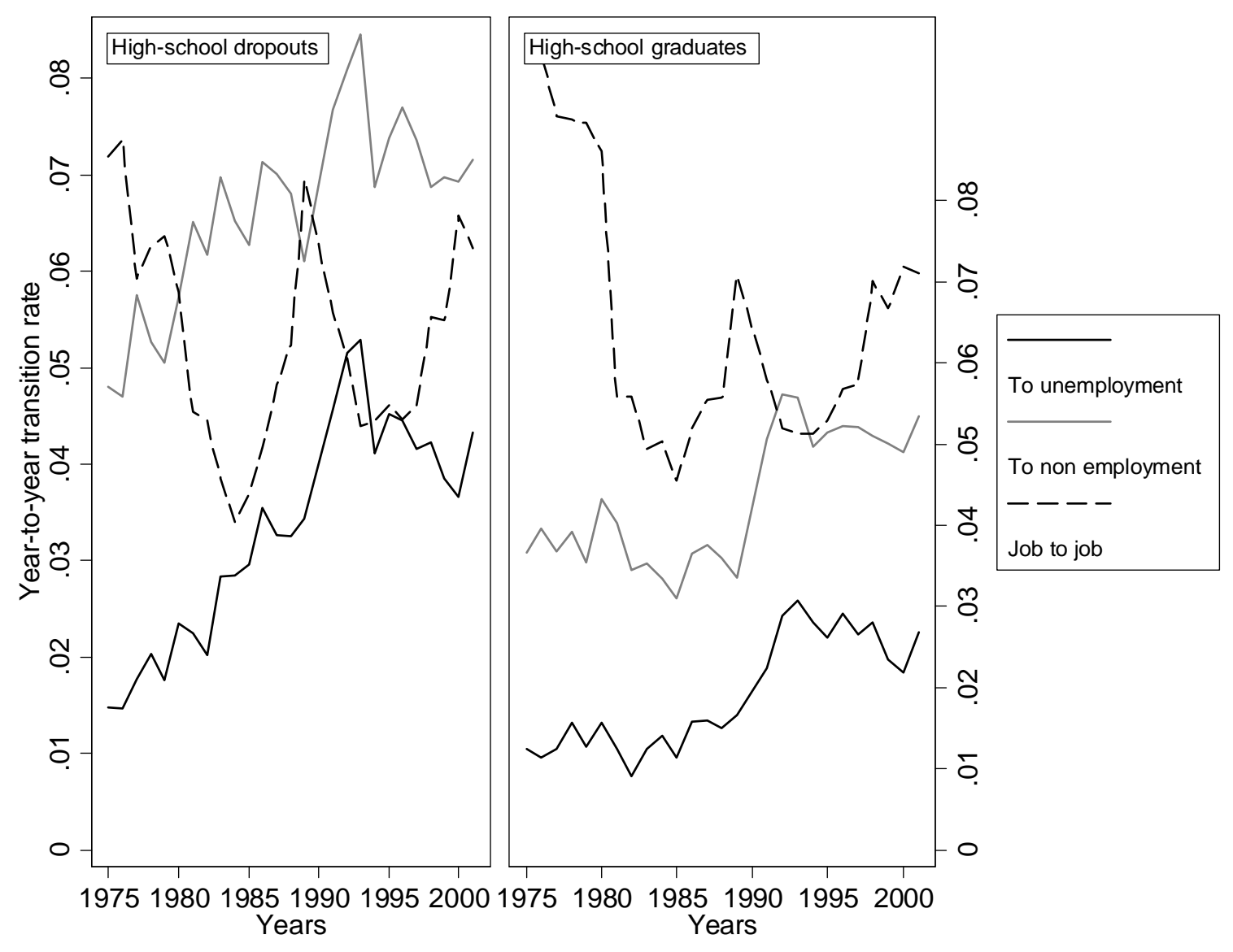


Figure 6: PC adoption by initial skill mix
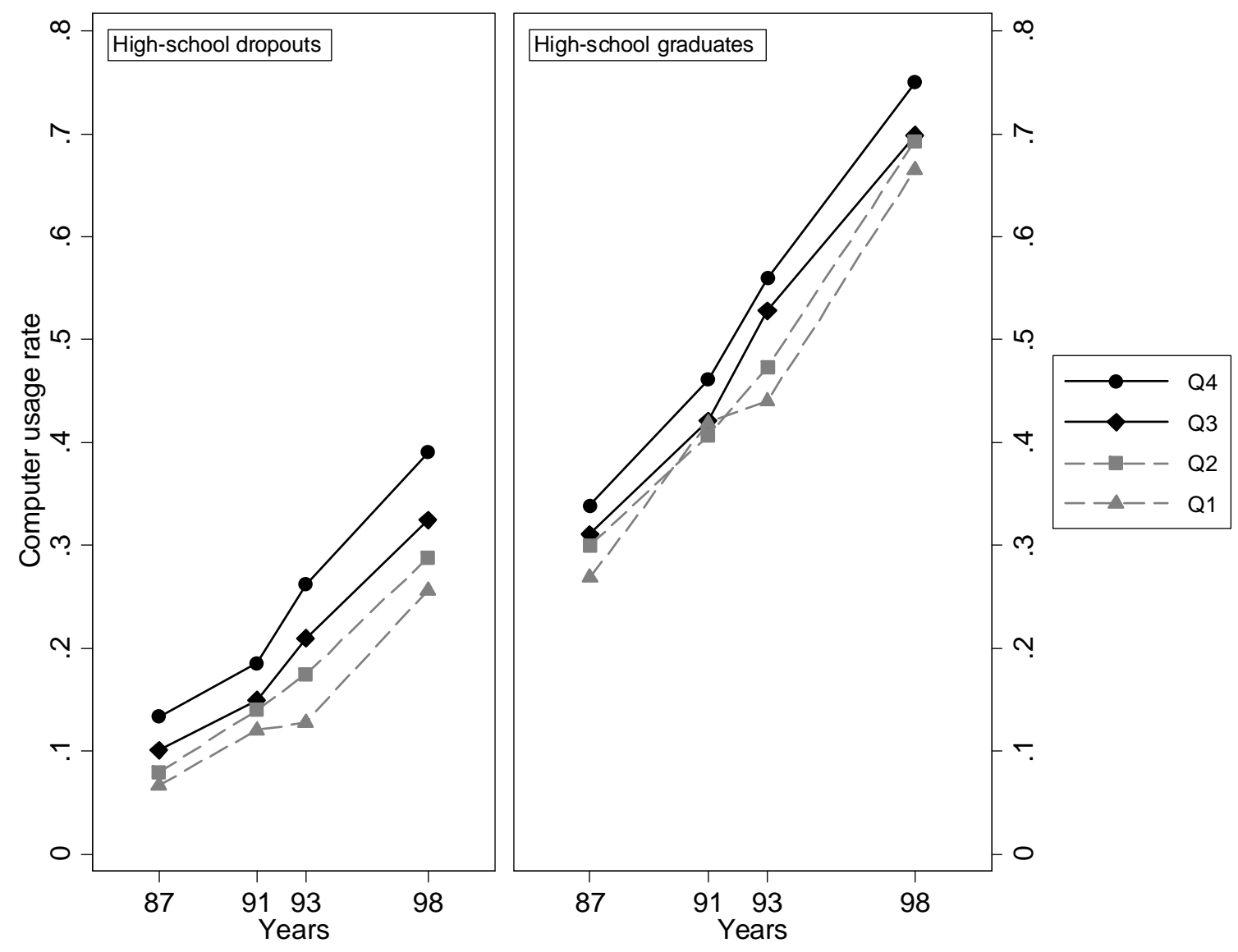
Figure 7: Transitions from employment to unemployment, by initial skilled labor endowment

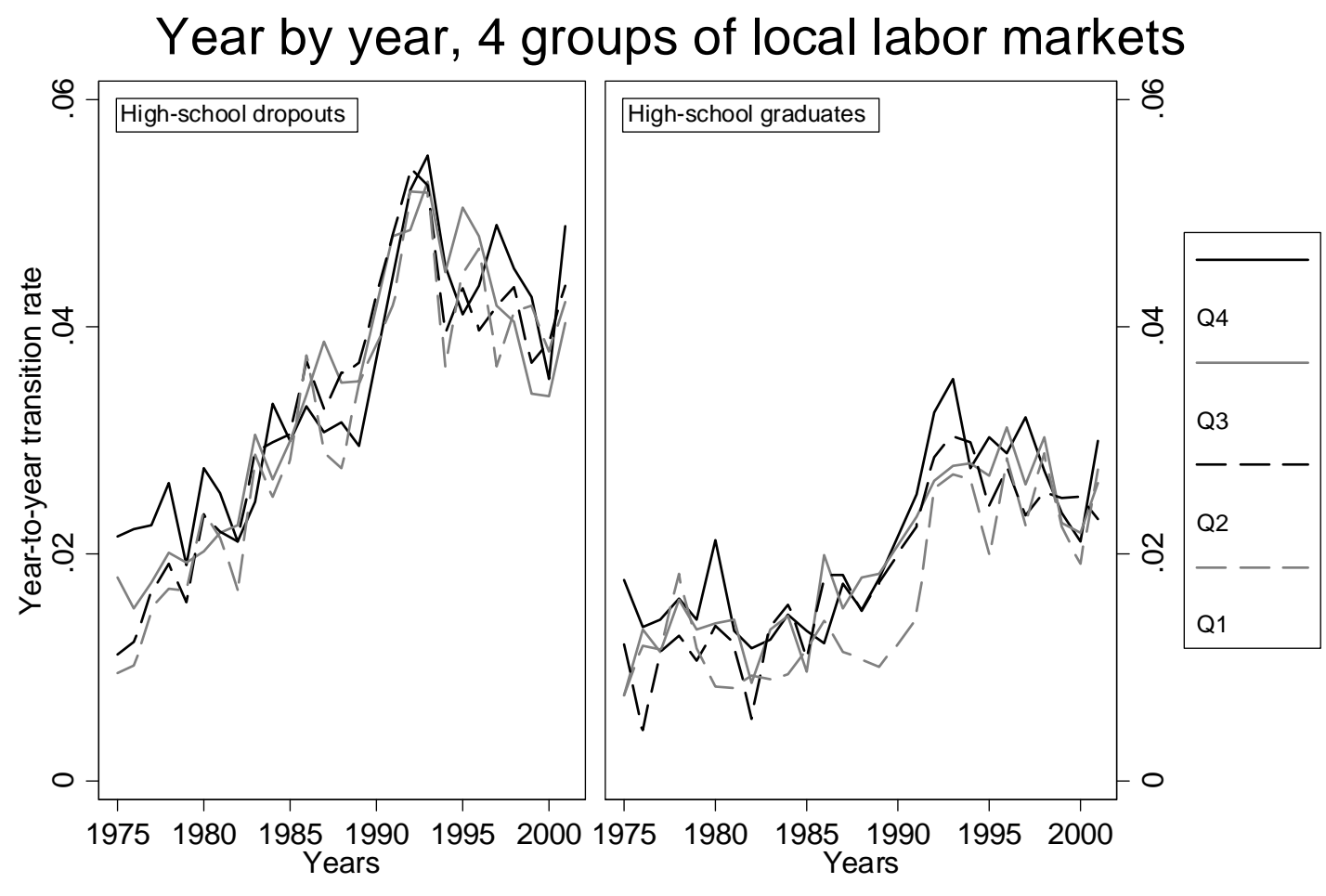

By 2-year periods, 2 groups

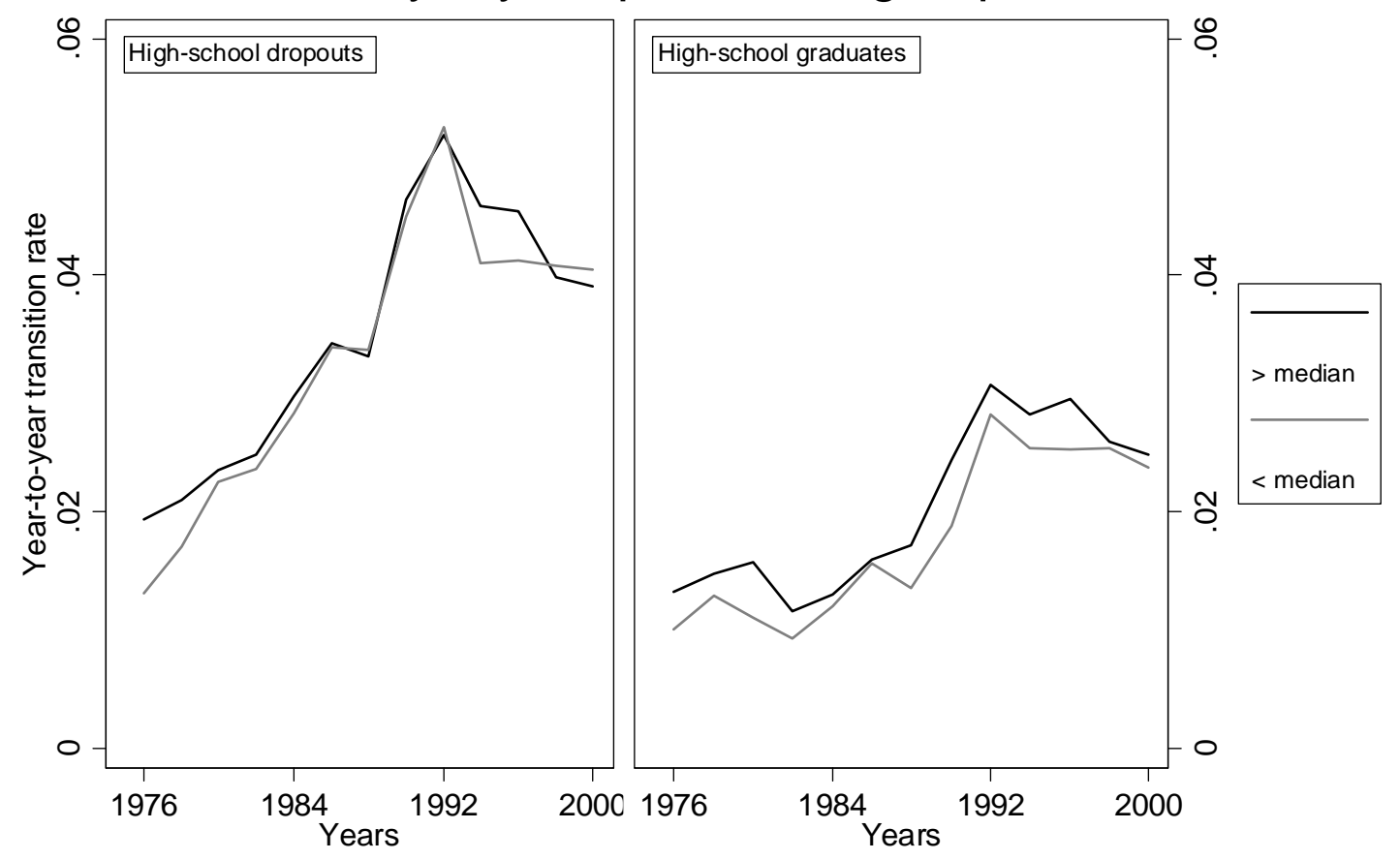


Figure 8: Transitions from employment to non employment, by initial skilled labor endowment
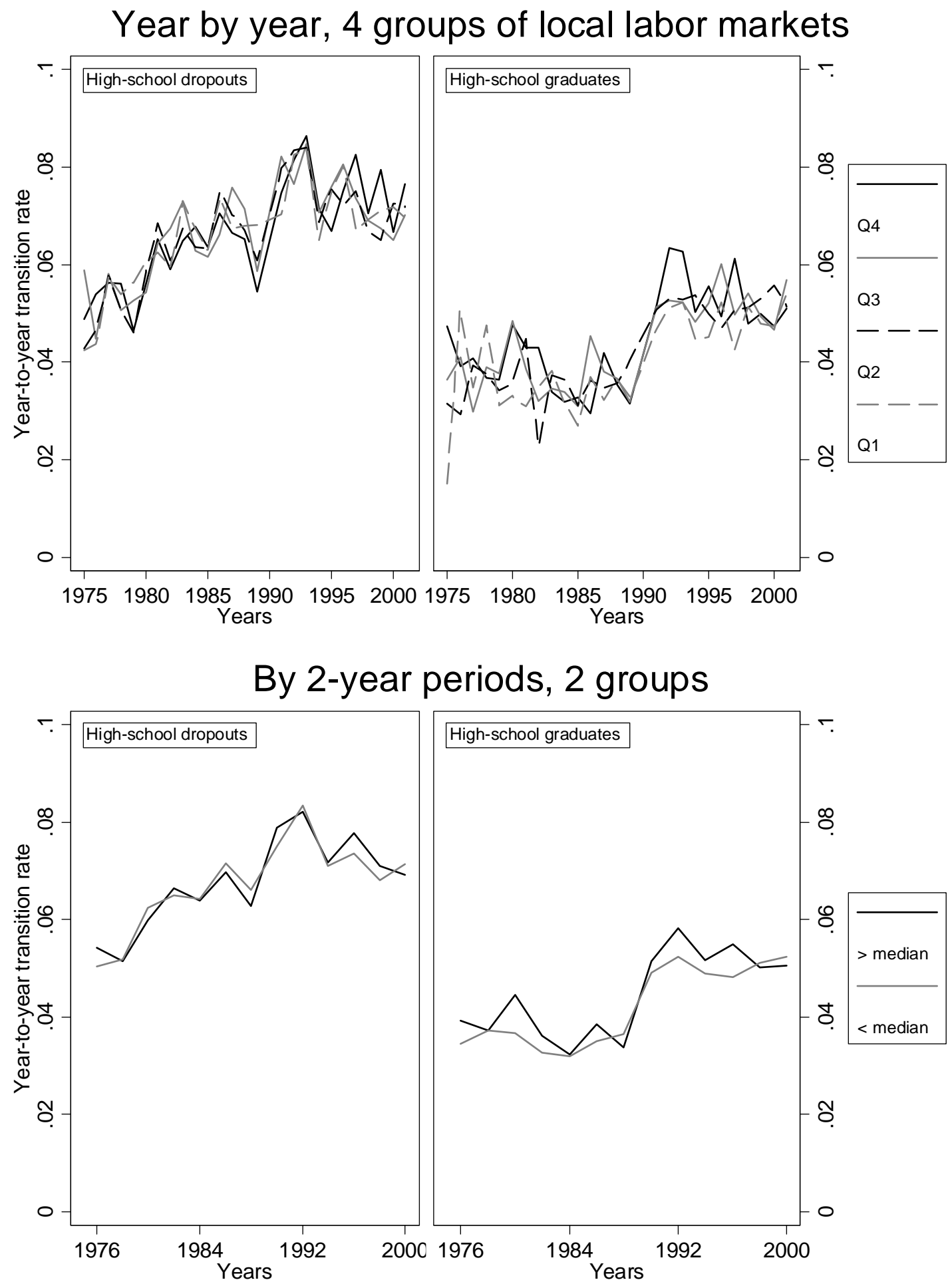
Figure 9: Job-to-job transitions by initial skilled labor endowment
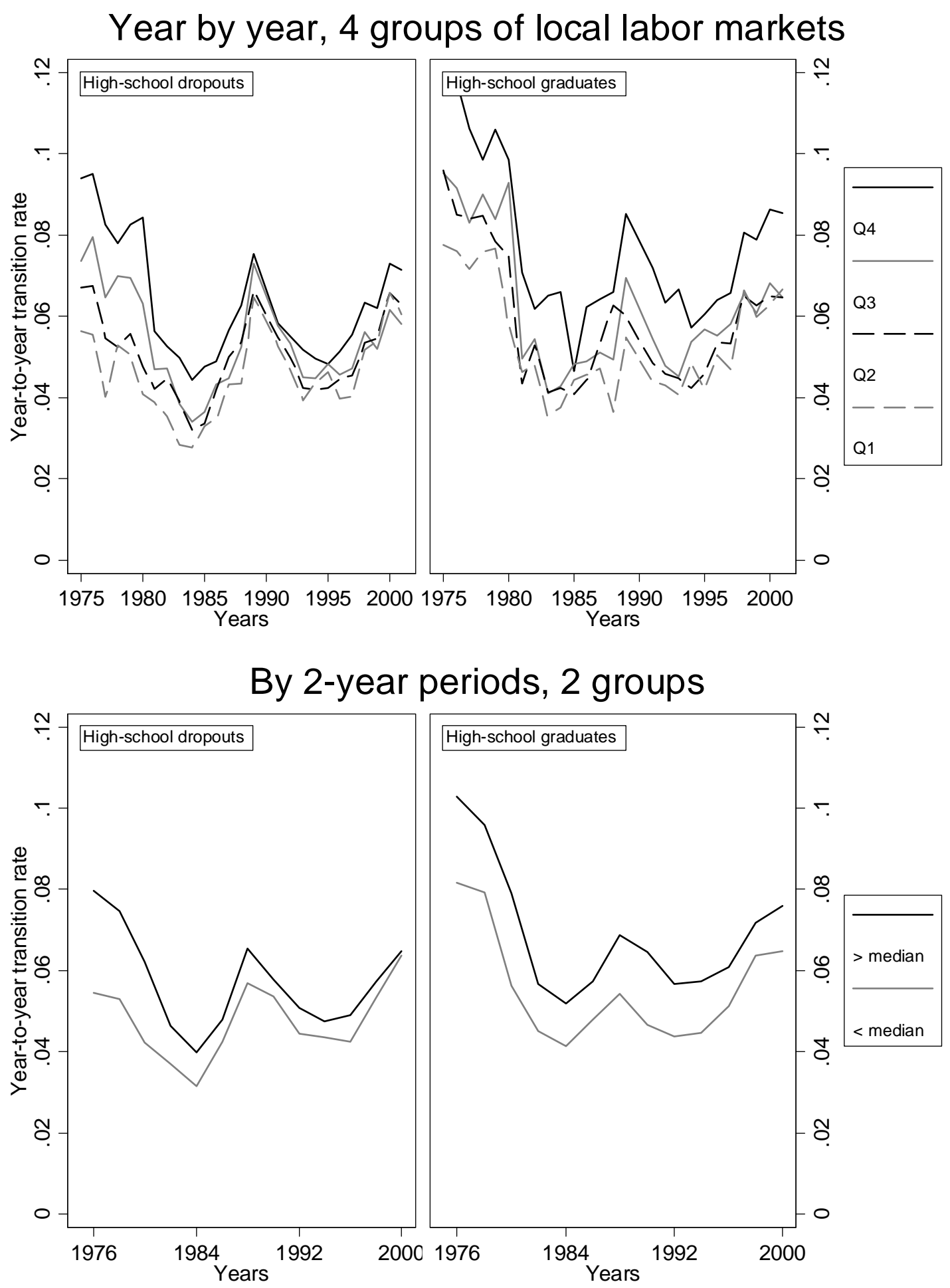


\section{Appendix}

\section{A1. Firm-level data and measure of firm strategies to upgrade the skill level of their workforce}

The data used in section 5 is from Behaghel et al. (2011). For convenience, this appendix summarizes the presentation of the data and of variables used in section 5, but a more detailed description is in the original paper.

The information on IT comes from the REPONSE survey (RElations PrOfessionnelles et NégocationS d'Entreprise). In 1998, 2978 establishments were surveyed with senior managers being asked questions about industrial relations, implementation of new technologies and reorganisations.

Worker flows, are from two different sources. The DMMO (Données sur les Mouvements de Main-d'Oeuvre) has exhaustive data on entries and exits of workers in and out of establishments with 50 employees or more. The data is broken down into four occupational categories: managers and professionals, ${ }^{21}$ technicians and supervisors, clerks and blue-collars. The EMMO (Enquête sur les Mouvements de Main-d'Oeuvre) has identical information on a representative sample of firms with less than 50 employees. We use this data to compute counterfactual changes in labour shares over 1996-1998, i.e. changes that are due only to entries and exits (resp. promotions) in the various occupations over the period. We also use information on the level of employment in each occupational cell at the beginning and at the end of the period. This information is provided by the French survey of employment structure: the ESE (Enquête Structure des Emplois), as of December $31^{\text {st }} 1995$ and 1998.

Last, the so-called 24-83 fiscal records provide firm-level data on the number of workers receiving training and the volume of training hours. ${ }^{22}$ This only refers to continuous and formal training. In particular, apprenticeship and informal on-the-job training are excluded. Using the information available in the $24-83$, we compute both the proportion of workers receiving some training and the average number of training hours per worker for four occupational categories - identical to those in the DMMO-EMMO database. These are averaged over 1996-1998.

\footnotetext{
${ }^{21}$ This category also includes engineers.

22 The 24-83 records provide firm rather than plant-level data on training. Matching them with establishmentlevel data generates some measurement error that is likely to raise the standard errors in our estimates.
} 
Matching the four datasets and cleaning out establishments with implausible values for skill upgrading reduces our sample to 1,114 establishments. The low matching rate is primarily due to the fact that the EMMO and 24-83 sources are not exhaustive (respectively, not systematically coded).

The share of occupational group $p$ in the workforce of firm $i$ is computed as:

$$
\Delta S_{i p}=\frac{L_{t}^{i p}}{L_{t}^{i}}-\frac{L_{t-1}^{i p}}{L_{t-1}^{i}} .
$$

The counterfactual changes in labour shares $\left(\Delta \tilde{S}_{i p}\right)$ describing what would have happened to the occupational structure if there had only been entries and exits at the different occupational levels, but no internal movement (promotion or demotion) is computed as:

$$
\Delta \tilde{S}_{i p}=\frac{L_{t-1}^{i p}+H_{t}^{i p}-E_{t}^{i p}}{L_{t-1}^{i}+H_{t}^{i}-E_{t}^{i}}-\frac{L_{t-1}^{i p}}{L_{t-1}^{i}}
$$

where $L_{t-1}^{i p}$ is the number of workers in occupation $p$ in firm $i$ at time $t-1, H_{t}^{i p}$ is the number of entries in occupation $p$ in firm $i$ between time $t-1$ and $t$ and $E_{t}^{i p}$ is the number of workers formerly employed in occupation $p$ leaving firm $i$ between time $t-1$ and $t$. Similarly, $L_{t}^{i}, H_{t}^{i}$, and $E_{t}^{i}$ respectively denote the total number of workers, entries and exits in firm $i$ at time $t$.

Changes in the occupational structure through promotions only $\left(\Delta \hat{S}_{i p}\right)$ are defined as the changes in the occupational structure that would have occurred if there had been none of the entries or exits that we observe in the data:

$$
\Delta \hat{S}_{i p}=\frac{L_{t}^{i p}-H_{t}^{i p}+E_{t}^{i p}}{L_{t}^{i}-H_{t}^{i}+E_{t}^{i}}-\frac{L_{t-1}^{i p}}{L_{t-1}^{i}}
$$

where $L_{t}^{i p}$ is the number of workers in occupation $p$ in firm $i$ at time $t$.

Excess turnover et in plant $i$ and for group $p$ is defined as:

$$
e t_{i p} \equiv \frac{H_{i p}+E_{i p}}{L_{i p}}-\left|\frac{H_{i p}-E_{i p}}{L_{i p}}\right| .
$$

Table A1 (replicating table A1 in Behaghel et al., 2011) displays descriptive statistics on the firm sample. 
Table A1: Descriptive statistics on the firm

sample

\begin{tabular}{|c|c|c|c|c|c|}
\hline & All plants & Internet/Intranet=0 & Internet/Intranet=1 & Manufacturing & Services \\
\hline \multicolumn{6}{|l|}{ Change of labor share (in \%) } \\
\hline Managers and professionals & 0.77 & 0.33 & 1.65 & 0.93 & 0,54 \\
\hline Technicians and su pervisors & 0.56 & 0.63 & 0.44 & 0.72 & 0,36 \\
\hline Clerks & -0.38 & -0.15 & -0.84 & -0.27 & $-0,53$ \\
\hline Blue collars & -0.95 & -0.81 & -1.24 & -1.38 & $-0,37$ \\
\hline \multicolumn{6}{|c|}{ Change of labor share through internal movements (in \%) } \\
\hline Managers and professionals & 0.92 & 0.60 & 1.55 & 0.90 & 0,93 \\
\hline Technicians and su pervisors & 0.79 & 0.73 & 0.92 & 0.96 & 0,56 \\
\hline Clerks & -0.64 & -0.38 & -1.16 & -0.41 & $-0,95$ \\
\hline Blue collars & -1.07 & -0.95 & -1.31 & -1.46 & $-0,55$ \\
\hline \multicolumn{6}{|c|}{ Change of labor share through entries and exits (in \%) } \\
\hline Managers and professionals & -0.07 & -0.18 & 0.15 & 0.07 & $-0,26$ \\
\hline Technicians and supervisors & -0.13 & 0.00 & -0.41 & -0.17 & $-0,09$ \\
\hline Clerks & 0.18 & 0.13 & 0.29 & 0.14 & 0,25 \\
\hline Blue collars & 0.02 & 0.04 & -0.02 & -0.04 & 0,10 \\
\hline \multicolumn{6}{|l|}{ Excess turnover (in \%) } \\
\hline Managers and professionals & 24.12 & 25.04 & 22.29 & 18.54 & 31,89 \\
\hline Technicians and supervisors & 25.13 & 27.38 & 20.67 & 13.95 & 40,55 \\
\hline Clerks & 61.10 & 61.07 & 61.16 & 30.13 & 102,88 \\
\hline Blue collars & 49.93 & 53.38 & 42.79 & 27.21 & 84,89 \\
\hline \multicolumn{6}{|l|}{ Number of trainees per 100 workers } \\
\hline Managers and professionals & 59.60 & 56.71 & 65.38 & 60.58 & 58,27 \\
\hline Technicians and supervisors & 59.59 & 55.47 & 67.94 & 60.94 & 57,62 \\
\hline Clerks & 41.27 & 37.88 & 48.06 & 43.82 & 37,83 \\
\hline Blue collars & 34.18 & 32.04 & 39.14 & 34.17 & 34,22 \\
\hline \multicolumn{6}{|l|}{ Hours of training per worker } \\
\hline Managers and professionals & 21.45 & 19.54 & 25.24 & 22.70 & 19,75 \\
\hline Technicians and su pervisors & 19.45 & 17.55 & 23.30 & 19.97 & 18,69 \\
\hline Clerks & 12.07 & 10.87 & 14.47 & 13.08 & 10,70 \\
\hline Blue collars & 9.49 & 8.27 & 12.31 & 10.31 & 7,63 \\
\hline Internet/Intranet & 0,33 & 0.00 & 1.00 & 0.34 & 0.32 \\
\hline Indicator for plant with more than 200 workers & 0,53 & 0.48 & 0.62 & 0.62 & 0.40 \\
\hline Indicator for dense local labor market & 0,25 & 0.21 & 0.34 & 0.20 & 0.32 \\
\hline Indicator for service sector & 0,42 & 0.43 & 0.41 & 0.00 & 1.00 \\
\hline Indicator for multi-establishment firm & 0,60 & 0.57 & 0.66 & 0.63 & 0.56 \\
\hline Indicator for public sector & 0,03 & 0.03 & 0.05 & 0.02 & 0.05 \\
\hline Indicator for listed company & 0,43 & 0.38 & 0.54 & 0.55 & 0.27 \\
\hline Indicator for presence of union delegates & 0,77 & 0.76 & 0.81 & 0.84 & 0.69 \\
\hline Share of women (\%) & 35,13 & 35.91 & 33.54 & 25.98 & 47.53 \\
\hline $\begin{array}{l}\text { Indicator for part-time work ( }>5 \% \text { of } \\
\text { workfo rce) }\end{array}$ & 0,37 & 0.37 & 0.38 & 0.22 & 0.58 \\
\hline Number of observations & 1114 & 747 & 367 & 641 & 473 \\
\hline
\end{tabular}


Table A2: IT adoption and skill upgrading channels: 2SLS estimates (instruments: 1(Educ $c_{c 0}>$ median); local labor market controls: region dummies and labor market density)

\begin{tabular}{|c|c|c|c|c|}
\hline & $\begin{array}{l}\text { Managers and } \\
\text { professionals }\end{array}$ & $\begin{array}{l}\text { Technicians and } \\
\text { supervisors }\end{array}$ & Clerks & Blue collars \\
\hline & \multicolumn{4}{|c|}{ A. Overall changes in the occupational structure } \\
\hline \multirow[t]{2}{*}{ Internet/Intranet } & $5.55^{\star \star}$ & 1.36 & -1.52 & -5.38 \\
\hline & $(2.47)$ & (3.08) & $(2.66)$ & (3.82) \\
\hline \multirow[t]{2}{*}{ Obs } & 1,109 & 1,109 & 1,109 & 1,109 \\
\hline & \multicolumn{4}{|c|}{ B. Internal movements } \\
\hline \multirow[t]{2}{*}{ Internet/Intranet } & 3.99 & 1.95 & -2.34 & -3.60 \\
\hline & $(2.81)$ & $(2.78)$ & (3.67) & (3.24) \\
\hline \multirow[t]{2}{*}{ Obs } & 1,109 & 1,109 & 1,109 & 1,109 \\
\hline & \multicolumn{4}{|c|}{ C. External movements } \\
\hline \multirow[t]{2}{*}{ Internet/Intranet } & 1.91 & -0.20 & -0.64 & -1.07 \\
\hline & $(1.72)$ & (2.62) & $(2.35)$ & $(3.21)$ \\
\hline \multirow[t]{2}{*}{ Obs } & 1,109 & 1,109 & 1,109 & 1,109 \\
\hline & \multicolumn{4}{|c|}{ D. Excess turnover } \\
\hline \multirow[t]{2}{*}{ Internet/Intranet } & -26.76 & 99.44 & 93.94 & 232.50 \\
\hline & (37.77) & (79.65) & (65.95) & (166.22) \\
\hline \multirow[t]{2}{*}{ Obs } & 1,085 & 1,090 & 1,099 & 1,041 \\
\hline & \multicolumn{4}{|c|}{ E. Number of trainees (per 100 workers) } \\
\hline \multirow[t]{2}{*}{ Internet/Intranet } & 43.38 & 66.93 & $52.40^{\star}$ & $49.96^{\star}$ \\
\hline & (30.23) & (52.59) & (30.14) & (26.19) \\
\hline \multirow[t]{2}{*}{ Obs } & 1,092 & 1,047 & 1,082 & 905 \\
\hline & \multicolumn{4}{|c|}{ F. Training hours per worker } \\
\hline \multirow[t]{2}{*}{ Internet/Intranet } & 8.29 & -0.72 & $19.19^{\star \star}$ & 8.55 \\
\hline & $(14.32)$ & $(13.38)$ & $(9.32)$ & $(7.23)$ \\
\hline Obs & 1,090 & 1,037 & 1,078 & 903 \\
\hline
\end{tabular}

See notes to table 7 
Table A3: IT adoption and skill upgrading channels: 2SLS estimates (instruments: Educ $c_{c 0}$ et $E d u c_{c 0}{ }^{2}$ )

\begin{tabular}{|c|c|c|c|c|}
\hline & $\begin{array}{l}\text { Managers and } \\
\text { professionals }\end{array}$ & $\begin{array}{c}\text { Technicians and } \\
\text { supervis ors }\end{array}$ & Clerks & Blue collars \\
\hline & \multicolumn{4}{|c|}{ A. Overall changes in the occupational structure } \\
\hline \multirow[t]{2}{*}{ Intemet/Intranet } & 5.59 *** & -1.48 & -1.94 & -2.18 \\
\hline & $(1.26)$ & $(1.11)$ & $(1.73)$ & $(1.50)$ \\
\hline \multirow[t]{2}{*}{ Obs } & 1,109 & 1,109 & 1,109 & 1,109 \\
\hline & \multicolumn{4}{|c|}{ B. Intemal movements } \\
\hline \multirow[t]{2}{*}{ Intemet/Intranet } & $4.45^{\star \star \star}$ & -0.66 & -1.91 & -1.88 \\
\hline & $(1.19)$ & $(1.69)$ & (1.61) & $(1.48)$ \\
\hline \multirow[t]{2}{*}{ Obs } & 1,109 & 1,109 & 1,109 & 1,109 \\
\hline & \multicolumn{4}{|c|}{ C. External movements } \\
\hline \multirow[t]{2}{*}{ Intemet/Intranet } & 1.36 & -0.86 & 0.29 & -0.78 \\
\hline & (1.26) & $(1.25)$ & $(0.74)$ & $(1.15)$ \\
\hline \multirow[t]{2}{*}{ Obs } & 1,109 & 1,109 & 1,109 & 1,109 \\
\hline & \multicolumn{4}{|c|}{ D. Excess tumover } \\
\hline \multirow[t]{2}{*}{ Intemet/Intranet } & 3.70 & 15.95 & $71.39^{\star \star}$ & 150.61 \\
\hline & (14.74) & $(15.49)$ & (32.52) & (126.28) \\
\hline \multirow[t]{2}{*}{ Obs } & 1,085 & 1,090 & 1,099 & 1,041 \\
\hline & \multicolumn{4}{|c|}{ E. Number of trainees (per 100 workers) } \\
\hline \multirow[t]{2}{*}{ Intemet/Intranet } & -3.84 & 21.83 & 13.72 & $38.83^{\star \star \star}$ \\
\hline & $(10.82)$ & $(25.16)$ & (10.69) & $(13.77)$ \\
\hline \multirow[t]{2}{*}{ Obs } & 1,092 & 1,047 & 1,082 & 905 \\
\hline & \multicolumn{4}{|c|}{ F. Training hours per worker } \\
\hline \multirow[t]{2}{*}{ Intemet/Intranet } & 0.34 & -0.64 & $8.40^{\star *}$ & $10.48^{\star \star \star}$ \\
\hline & (5.09) & $(5.55)$ & $(4.27)$ & (3.61) \\
\hline Obs & 1,090 & 1,037 & 1,078 & 903 \\
\hline
\end{tabular}

See notes to table 7 . 